\title{
Intramolecular Condensation Reactions in Protonated Dipeptides: Carbon Monoxide, Water, and Ammonia Losses in Competition
}

\author{
Francesco Pingitore, Michael J. Polce, Ping Wang, \\ and Chrys Wesdemiotis \\ Department of Chemistry, The University of Akron, Akron, Ohio, USA
}

Béla Paizs

Protein Analysis Facility, German Cancer Research Center, Heidelberg, Germany

\begin{abstract}
The elimination of carbon monoxide and water from a series of protonated dipeptides, $[\mathrm{XxxYyy}+\mathrm{H}]^{+}$, is investigated by tandem mass spectrometry experiments and density functional theory. The combined results show that $\mathrm{CO}$ loss occurs on the $\mathrm{a}_{1}-\mathrm{y}_{1}$ pathway, which begins by rearrangement of the added proton to the amide $\mathrm{N}$-atom and creates the proton-bound dimer of an amino acid (Yyy) and an imine (that from Xxx residue). The loss of $\mathrm{H}_{2} \mathrm{O}$ is initiated from a tautomer in which the added proton has migrated to the hydroxyl group of the C-terminus, thereby promoting the formation of an ion with protonated oxazolone structure (a nominal $\mathrm{b}_{2}$ ion). The highest yields of $\left[\mathrm{XxxYyy}+\mathrm{H}-\mathrm{CO}^{+}\right.$and $\left[\mathrm{XxxYyy}+\mathrm{H}-\mathrm{H}_{2} \mathrm{O}\right]^{+}$are observed at threshold energies. As the internal energy of the protonated dipeptides increases, these primary products are depleted by consecutive dissociations yielding mostly backbone fragments. Specifically, $[\mathrm{XxxYyy}+\mathrm{H}-\mathrm{CO}]^{+}$decomposes to $\mathrm{y}_{1}$ (protonated Yyy) and $\mathrm{a}_{1}$ (immonium ion of $\mathrm{Xxx}$ residue), while [XxxYyy $\left.+\mathrm{H}-\mathrm{H}_{2} \mathrm{O}\right]^{+}$ produces $\mathrm{a}_{2}$ and the immonium ions of residues $\mathrm{Xxx}\left(\mathrm{a}_{1}\right)$ and Yyy ("internal" immonium ion). Water loss takes place more efficiently when the more basic residue is at the C-terminal position. Increasing the basicity of the $\mathrm{N}$-terminal residue enhances the extent of $\mathrm{CO}$ versus $\mathrm{H}_{2} \mathrm{O}$ loss and introduces the competitive elimination of $\mathrm{NH}_{3}$. The dissociations leading to eliminations of small neutrals $\left(\mathrm{CO}, \mathrm{H}_{2} \mathrm{O}\right.$, etc.) generally proceed over transition states that lie higher in energy than the corresponding dissociation products. The excess energy is disposed of either in translational or rovibrational modes of the products, depending on the stability of the incipient noncovalent assemblies emerging during the cleavage of the small neutrals. (J Am Soc Mass Spectrom 2004, 15, 1025-1038) (C 2004 American Society for Mass Spectrometry
\end{abstract}

$\mathrm{W}$ hen protonated peptides are activated to dissociate, they undergo backbone cleavages, dissociations in the side chains, as well as condensation reactions releasing small neutrals such as water, carbon monoxide, ammonia, or a combination thereof [1-3]. A large number of experimental and computational studies thus far have focused on the backbone and side chain fragmentations, which reveal sequence and/or compositional information [4-26]. On

Published online June 11, 2004

Dedicated to Professor Fred W. McLafferty on the occasion of his Distinguished Contribution in Mass Spectrometry Award and in recognition of the enormous impact of the McLafferty rearrangement on the discovery of new specific and structurally valuable gas-phase ion rearrangements.

Address reprint requests to Dr. C. Wesdemiotis, Department of Chemistry, The University of Akron, 190 E. Buchtel Commons, Akron, OH 44325-3601, USA. E-mail: wesdemiotis@uakron.edu the other hand, the decompositions leading to the losses of small neutrals have drawn less attention, presumably because they do not directly relate sequence insight [4, $12-14,22,26]$. The importance of understanding the mechanisms of the latter reactions has, however, been emphasized, as the resulting condensation products may fragment further to structurally diagnostic sequence ions $[23,24]$.

The elimination of water from protonated peptides has been the most extensively investigated small neutral loss. Studies by Harrison et al. [6], O'Hair et al. [12], and Aviyente et al. [26] have conclusively shown that dipeptides with an underivatized $\mathrm{COOH}$ terminus and no serine or threonine residues primarily dehydrate at the C-terminus, yielding an N-protonated oxazolone; this structure corresponds to an N-terminal $b_{2}$ backbone ion having the same number of amino acid residues as 
the precursor peptide ion. Ballard and Gaskell [4] and $\mathrm{O}^{\prime}$ Hair et al. [14] further reported that protonated peptides with three and more amino acid residues, or with hydroxy substituted side chains, lose water largely from the backbone amide groups, or the side chains, respectively, to generate fragment ions that do not have protonated oxazolone structures. Barely any data exist on the ammonia loss from the backbone of underivatized [peptide $+\mathrm{H}^{+}$ions. O'Hair et al. observed this reaction from the protonated methyl ester of CysGly, viz. $\mathrm{CysGlyOCH}_{3}$, but not from the isomeric [GlyCys$\left.\mathrm{OCH}_{3}+\mathrm{H}\right]^{+}$ion which instead loses water (as does the underivatized [GlyCys $+\mathrm{H}]^{+}$) [13]. Conflicting results have been reported for the $\mathrm{CO}$ loss from protonated peptides. Laskin et al. suggested that the $\mathrm{CO}$ moiety eliminated from [AlaAla $+\mathrm{H}]^{+}$originates from the carboxyl terminus [22]. In contrast, density functional theory calculations by Paizs and Suhai on [GlyGly + $\mathrm{H}]^{+}$predicted that CO loss occurs on a pathway involving the N-terminally located carbonyl group and ultimately leading to $a_{1}$ and $y_{1}$ fragments (the " $a_{1}-y_{1}$ " pathway) [23]. These two pathways generate distinct ion-molecule complexes composed of an imine and an amino acid [22, 23]. The present study undertakes an experimental and computational inquiry into the detailed mechanism of $\mathrm{CO}$ loss from protonated dipeptides and the influence of the peptide composition and sequence on the competition between $\mathrm{CO}$ loss and the losses of other small neutrals including ammonia and, in particular, water. The products arising from such dissociations generally dominate at low internal energies [22] and, as has recently been proposed [23, 24], they can fragment consecutively to sequence-diagnostic ions. Hence, elucidation of the formation pathways and energetics of $\mathrm{CO}, \mathrm{H}_{2} \mathrm{O}$, or other small neutral eliminations from protonated peptides should also improve our understanding on how sequence-revealing backbone ions are formed.

\section{Methods}

\section{Tandem Mass Spectrometry (MS/MS) Experiments}

The experiments were conducted on a Micromass AutoSpec-Q tandem mass spectrometer of EBEhQ geometry $(\mathrm{E}$, electric sector; $\mathrm{B}$, magnetic sector; $\mathrm{h}$, RF-only hexapole; $Q$, quadrupole mass filter) $[27,28]$ or a Bruker Esquire ion trap mass spectrometer [28-30]. In the hybrid instrument, protonated peptides were formed by fast atom bombardment (FAB) ionization, using 12 $\mathrm{keV} \mathrm{Cs}^{+}$ions as bombarding particles and sulfuric acid as the matrix. A few $\mu \mathrm{L}$ of a saturated solution of the peptide of interest in the matrix were introduced into the ion source and bombarded by $\mathrm{Cs}^{+}$. The peptide [M $+\mathrm{H}]^{+}$ions formed in this process were accelerated to 8 $\mathrm{keV}$ and mass-selected by the EB sectors for measurement of their metastable ion (MI) and collisionally activated dissociation (CAD) tandem mass spectra at high kinetic energy in the field-free region (FFR) be- tween EB and the subsequent electric sector. The product ions from these reactions were mass-analyzed by scanning the second electric sector. In CAD mode, one of the collision cells situated in the FFR was pressurized with argon to effect $80 \%$ transmittance of the $[\mathrm{M}+\mathrm{H}]^{+}$ beam. In $\mathrm{MS}^{3}$ experiments, a specific fragment from metastable $[\mathrm{M}+\mathrm{H}]^{+}$ions dissociating in the field-free region in front of the first electric sector was transmitted through EB by proper adjustment of the E and B fields, and the corresponding high-energy CAD spectrum was acquired using the above mentioned collision cell. Lowenergy CAD spectra (MS ${ }^{2}$ mode) were also obtained by transmitting the $[\mathrm{M}+\mathrm{H}]^{+}$ions through all three sectors (EBE), decelerating them to $<100 \mathrm{eV}$, and subjecting them to collisions with argon in the RF-only hexapole $\left(\sim 1 \times 10^{-6}\right.$ mbar Ar pressure); the fragments formed were subsequently mass-analyzed by $\mathrm{Q}$ scans. In the low-energy regime, CAD spectra were measured as a function of collision energy (energy-resolved $\mathrm{MS}^{2}$ spectra). For the fragments in the MI spectra of $[\mathrm{M}+\mathrm{H}]^{+}$ measured at high kinetic energy, the accompanying kinetic energy releases were calculated using fragment peak widths at half height $\left(\mathrm{T}_{0.5}\right)$ [31]; the quoted $\mathrm{T}_{0.5}$ values were corrected for the main beam width using established procedures [32, 33]. Approximately 100-200 scans were summed per MI, CAD, or $\mathrm{MS}^{3}$ experiment, depending on the intensity of the main beam. The reproducibility of relative abundances was better than $\pm 15 \%$.

Electrospray ionization (ESI) was utilized to form the peptide ions examined in the ion trap. Each peptide was dissolved in a 1:1 methanol/water mixture to form a $10^{-4} \mathrm{M}$ solution, which was introduced into the ESI ion source via a syringe pump at a rate of $150 \mu \mathrm{L} / \mathrm{h}$. The entrance of the sampling capillary was set at $-4 \mathrm{kV}$. Nitrogen served as the nebulizing gas (1 psi) and drying gas $\left(150{ }^{\circ} \mathrm{C}, 10 \mathrm{~L} / \mathrm{min}\right)$. These conditions led to intense $[\mathrm{M}+\mathrm{H}]^{+}$ions. CAD tandem mass spectra $\left(\mathrm{MS}^{2}\right)$ of $[\mathrm{M}$ $+\mathrm{H}^{+}$were acquired by ejecting all ions from the trap except $[\mathrm{M}+\mathrm{H}]^{+}$, which was then excited to fragment with a radiofrequency field that was turned on for 40 ms at an amplitude $\left(\mathrm{V}_{p-p}\right)$ of $0.4-0.6 \mathrm{~V}$; the $[\mathrm{M}+\mathrm{H}]^{+}$ ions were accelerated by the RF field and underwent CAD with the helium buffer gas in the trap [30, 34]. $\mathrm{MS}^{3}$ spectra were obtained by isolating in the trap a fragment from $[\mathrm{M}+\mathrm{H}]^{+}$(formed as described) and following the same procedure as with the isolated $[\mathrm{M}+\mathrm{H}]^{+}$. Ten scans per $\mathrm{MS}^{2}$ or $\mathrm{MS}^{3}$ spectrum were scanned to achieve a reproducibility of relative abundances of ca. $\pm 15 \%$. The peptides and the solvents or reagents used in the FAB and ESI experiments were purchased from Sigma or Aldrich and were used in the condition received.

\section{Density Functional Theory Calculations}

Calculations were performed on the potential energy surface (PES) for $\mathrm{H}_{2} \mathrm{O}$ loss from protonated GlyGly and the consecutive decompositions of the initial [GlyGly + 
Table 1. Metastable ion (MI) mass spectra of the $[\mathrm{M}+\mathrm{H}]^{+}$ions generated by FAB ionization of dipeptides ${ }^{\mathrm{a}}$

\begin{tabular}{|c|c|c|c|c|c|c|}
\hline Dipeptide & $\mathrm{NH}_{3}$ loss & $\mathrm{H}_{2} \mathrm{O}$ loss $\left(\mathrm{b}_{2}\right)$ & CO loss & $\mathrm{H}_{2} \mathrm{O}+\mathrm{CO}$ loss $\left(\mathrm{a}_{2}\right)$ & $y_{1}$ & $a_{1}$ \\
\hline GlyGly & & $22(0.02)$ & $100(0.33)$ & & $36(0.04)$ & $1(0.03)$ \\
\hline GlyAla & & $100(0.03)$ & $9(0.44)$ & $4(0.11)$ & $56(0.09)$ & \\
\hline AlaGly & & $3(0.02)$ & $100(0.54)$ & & & $24(0.04)$ \\
\hline AlaAla & & $27(0.02)$ & $100(0.51)$ & & $3(0.03)$ & $32(0.03)$ \\
\hline Alalle & & $100(0.06)$ & $2(0.50)$ & $45(0.25)$ & $79(0.12)$ & $3(0.04)$ \\
\hline IleAla & & $2(0.02)$ & $7(0.64)$ & & & $100(0.06)$ \\
\hline GlyAsp & & $100(0.04)$ & & & $55(0.10)$ & \\
\hline AspGly & & $100(0.05)$ & & & & $<1(0.06)$ \\
\hline GlyPhe & & $85(0.03)$ & & $43(0.17)$ & $100(0.10)$ & \\
\hline PheGly & $4(0.01)$ & $3(0.01)$ & $4(0.39)$ & & & $100(0.09)$ \\
\hline AlaTrp ${ }^{c}$ & & $19(0.08)$ & & $6(0.21)$ & $100(0.14)$ & $<1(0.06)$ \\
\hline TrpAla & $100(0.07)$ & & & & & $7(0.08)$ \\
\hline
\end{tabular}

${ }^{a}$ Relative abundance in \% of base peak intensity, using peak areas, followed (in parenthesis and italicized) by $\mathrm{T}_{0.5}$ in eV.

${ }^{b} \mathrm{~A}$ weak fragment is present at $m z 88$ (loss of $\mathrm{CO}+\mathrm{NH}_{3}$ ) but is obscured by a nearby artifiact peak (Figure 1a).

'Other fragments, \% ( $\mathrm{T}_{0.5}$ in $\left.\mathrm{eV}\right)$ : $\mathrm{NH}_{3}$ loss from $\mathrm{y}_{1}, 6$ (0.07); indolyl (side chain) ion at $\mathrm{m} / \mathrm{z} 130,10(0.11)$.

$\mathrm{H}-\mathrm{CO}^{+}$fragment. The geometries and vibrational frequencies of the precursor ion, transition structures, intermediate ion-molecule complexes, and final fragmentation products were computed at the B3LYP level of density functional theory (DFT) in conjunction with 6-31 + G(d,p) basis sets. When necessary, intrinsic reaction coordinate (IRC) calculations were carried out for transition states (TS) to determine the minima with which the investigated TS were connected. The calculations were performed using the Gaussian-98 program system [35].

\section{Results and Discussion}

\section{Fragmentations of Metastable Protonated Dipeptides}

Table 1 lists the MI spectra of the $[\mathrm{M}+\mathrm{H}]^{+}$ions from the dipeptides (XxxYyy) studied. Metastable ions have a narrow range of usually low internal energies [31-33], which leads to the generation of relatively few fragments. At keV kinetic energies, metastable fragmentations take place within microseconds. In this time span, the aliphatic $[\mathrm{XxxYyy}+\mathrm{H}]^{+}$produce significant fragment ions by $\mathrm{CO}$ elimination. In contrast, this reaction does not yield observable signals with side-chain functionalized dipeptides except for PheGly. When observed, CO loss consistently proceeds with substantial release of internal energy into translational modes, as is evident from the corresponding flat-topped peak shapes and broad peak widths (cf. Figure 1 and $\mathrm{T}_{0.5}$ values in Table 1). The kinetic energy releases measured lie in the $0.3-0.6 \mathrm{eV}$ range, which is indicative of dissociation with a substantial reverse barrier, i.e., over a transition state that lies higher in energy than the products. Tight rearrangements are usually associated with such characteristics [31-33].

Besides protonated TrpAla, all [XxxYyy $+\mathrm{H}]^{+}$ions examined lose $\mathrm{H}_{2} \mathrm{O}$ within the $\mu$ s time window of MI fragmentations. The product ions emerging from this reaction have the composition of $\mathrm{N}$-terminal $b_{2}$ ions.
Elimination of water gives rise to peaks of Gaussian shape (Figure 1) and, compared to the loss of $\mathrm{CO}$, is associated with markedly smaller kinetic energy releases, ranging between 0.01 and $0.08 \mathrm{eV}$ (Table 1). Some of the $\mathrm{T}_{0.5}$ values observed are slightly higher than kinetic energy releases found upon dissociations with no reverse barrier (typically $\leq 0.03 \mathrm{eV}$ ) [31-33]. The excess could originate from kinetic shifts, which can be substantial for ions of the size of protonated dipeptides that must dissociate within a few microseconds [11, 22]; alternatively, $\mathrm{H}_{2} \mathrm{O}$ loss may take place over an appreciable reverse barrier, but the excess energy of the products is dissipated into internal and not translational degrees of freedom. More information on the actual mechanism is provided by the DFT calculations discussed later.

When water loss is the major metastable decomposition channel, the competitive elimination of $\mathrm{CO}$ is either suppressed or absent. For the dipeptides whose metastable $[\mathrm{M}+\mathrm{H}]^{+}$ions undergo both $\mathrm{CO}$ and $\mathrm{H}_{2} \mathrm{O}$

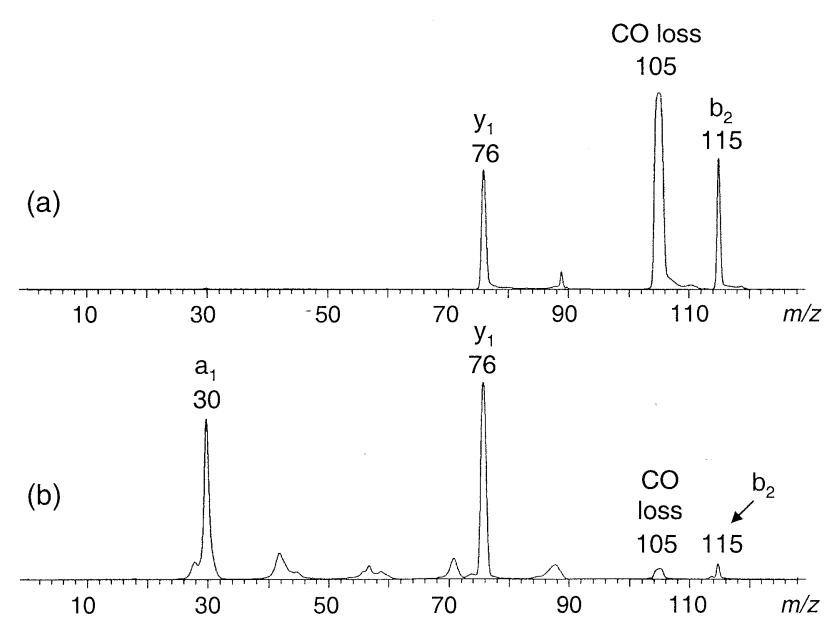

Figure 1. (a) MI and (b) high-energy $\mathrm{CAD}\left(\mathrm{MS}^{2}\right)$ spectra of FAB-generated [GlyGly $+\mathrm{H}]^{+}$ions $(m / z 133)$ with $8.0 \mathrm{keV}$ kinetic energy. 
Table 2. Proton affinities (PA) of amino acids and imines relevant to the dipeptides studied

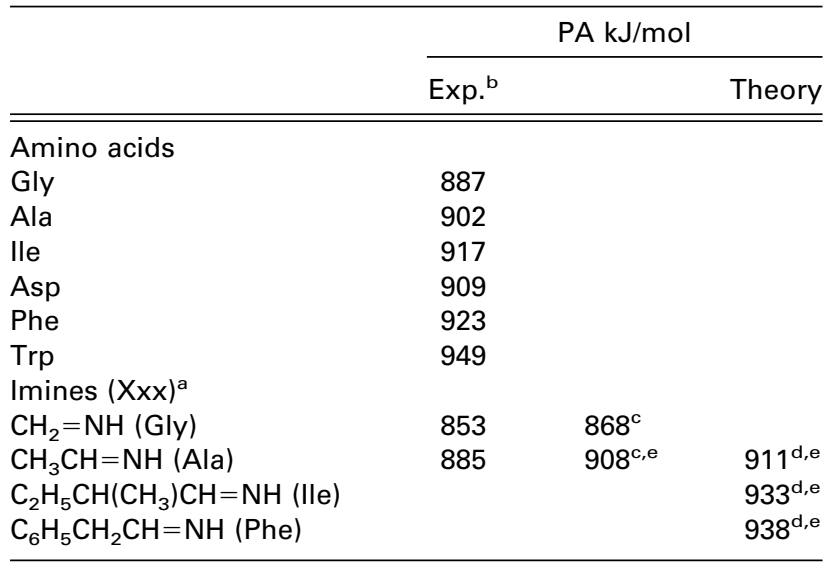

All data are from reference [36] unless noted otherwise.

${ }^{a}$ The amino acid corresponding to the imine shown is given in parenthesis.

${ }^{\mathrm{b}}$ Ref. [36].

${ }^{\mathrm{C}} \mathrm{G} 2$ values from ref. [37].

${ }^{\mathrm{d}}$ DFT values from ref. [38]

Mean value of proton affinities of cis and trans isomers. For the imines shown, $\mathrm{PA}$ (cis isomer) - PA(trans isomer) $\approx 2-3 \mathrm{~kJ} / \mathrm{mol}$.

elimination, the loss of $\mathrm{CO}$ is favored when the more basic residue (Table 2) [36-38] resides at the N-terminus, while the loss of $\mathrm{H}_{2} \mathrm{O}$ is favored with the reverse sequence, cf. AlaGly versus GlyAla, IleAla versus AlaIle, or PheGly versus GlyPhe in Table 1.

Two of the dipeptide ions studied, [PheGly $+\mathrm{H}]^{+}$ and $[\operatorname{TrpAla}+\mathrm{H}]^{+}$, lose $\mathrm{NH}_{3}$ in the metastable time frame. Relatively narrow, Gaussian peaks result from this process, which competes effectively against alternative dissociation channels only if an amino acid of high proton affinity (Table 2) is incorporated at the $\mathrm{N}$-terminus. On the other hand, all metastable [XxxYyy $+\mathrm{H}]^{+}$ions decompose to produce N-terminal $\mathrm{a}_{1}$ and/or C-terminal $y_{1}$ sequence ions (Table 1). Previous studies unequivocally established that $\mathrm{a}_{1}$ is the immonium ion of the $X_{x x}$ residue [2] and $y_{1}$ the protonated C-terminal amino acid, i.e., $[\mathrm{Yyy}+\mathrm{H}]^{+}[5]$. The abundance ratio of $\mathrm{a}_{1}$ and $\mathrm{y}_{1}$ is found to depend strongly on dipeptide composition and sequence [38]. From dipeptides consisting of two different amino acids, an abundant $y_{1}$ ion is formed if the more basic residue is located at the C-terminus, whereas the $\mathrm{a}_{1}$ ion predominates (relative to $y_{1}$ ) if the more basic residue occupies the $\mathrm{N}$-terminal position. Both $\mathrm{a}_{1}$ and $\mathrm{y}_{1}$ appear as Gaussian signals in the MI spectra and the kinetic energy releases associated with their formation are moderate (0.03-0.14 $\mathrm{eV})$; these features do not provide definitive mechanistic information about the pathway leading to $\mathrm{a}_{1}$ or $\mathrm{y}_{1}$, as reasoned above for the water elimination.

A third sequence ion, $\mathrm{a}_{2}$, which nominally arises by $\mathrm{CH}_{2} \mathrm{O}_{2}(46 \mathrm{u})$ loss from $[\mathrm{M}+\mathrm{H}]^{+}$, is observed from GlyAla, AlaIle, GlyPhe, and AlaTrp (Table 1), viz. XxxYyy dipeptides carrying the more basic residue at the C-terminus (Table 2). The formation of $\mathrm{a}_{2}$ releases significant kinetic energy and produces non-Gaussian

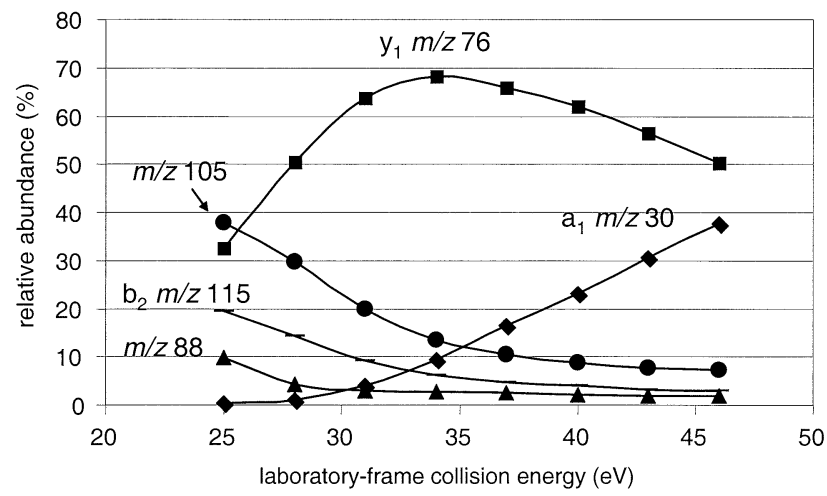

Figure 2. Breakdown graph for FAB-generated [GlyGly $+\mathrm{H}]^{+}$ ions $(m / z$ 133).

fragment ion peaks, indicating that it must overcome a barrier lying higher in energy than the products [31-33]. Such energetics has been reported for the loss of $\mathrm{CO}$ from $b_{2}$ ions with a protonated oxazolone structure [6]. Hence, the MI characteristics of $\mathrm{a}_{2}$ are consistent with generation of this ion via the sequence $\left[\mathrm{M}+\mathrm{H}^{+} \rightarrow \mathrm{b}_{2}\right.$ $\left(+\mathrm{H}_{2} \mathrm{O}\right) \rightarrow \mathrm{a}_{2}(+\mathrm{CO})$.

\section{Collisionally Activated Dissociation (CAD) of Protonated Dipeptides}

CAD of $[X x x Y y y+H]^{+}$at low collision energy (eV range) yields the same types of fragments as metastable dissociation, but the fragment ion abundances vary strongly with collision energy. MI and CAD fragmentation patterns look strikingly similar at low collision energies. A breakdown graph for $[\mathrm{GlyGly}+\mathrm{H}]^{+}$, i.e., a plot of relative fragment ion abundances in CAD spectra versus collision energy (Figure 2), shows that the losses of $\mathrm{CO}(\mathrm{m} / \mathrm{z} 105)$ and $\mathrm{H}_{2} \mathrm{O}(\mathrm{m} / \mathrm{z} 115)$ proceed with high yield at the lowest collision energies, at which the internal energy deposited onto $[\mathrm{M}+\mathrm{H}]^{+}$is low. As the internal energy of the decomposing $[\mathrm{M}+\mathrm{H}]^{+}$ions is raised, the extent of $\mathrm{CO}$ and $\mathrm{H}_{2} \mathrm{O}$ loss is reduced substantially, and $\mathrm{y}_{1}$ formation becomes the predominant decomposition channel over a wide range of collision energies. At even higher collision (internal) energies, a slight decrease is observed in the relative abundance of $\mathrm{y}_{1}$, accompanied by a considerable increase in the relative abundance of $a_{1}$. The backbone ions $\mathrm{y}_{1}$ and $\mathrm{a}_{1}$ are the major CAD products at the highest collision energies employed; these fragments also dominate the CAD spectrum acquired in the $\mathrm{keV}$ domain (Figure 1b).

The CAD and MI spectra of $[\text { GlyGly }+\mathrm{H}]^{+}$show a fragment at $m / z 88$, which is most efficiently formed at low collision energies (Figure 2). This fragment is formally generated by successive elimination of $\mathrm{CO}$ and $\mathrm{NH}_{3}$; corroborating evidence for this dissociation sequence will be presented later when the structure of the fragment from $\mathrm{CO}$ elimination is discussed. The elimination of $\mathrm{CO}+\mathrm{NH}_{3}$ is most abundant for GlyGly and 
Table 3. $\mathrm{CAD}\left(\mathrm{MS}^{3}\right)$ spectra of $[\mathrm{XxxYyy}+\mathrm{H}-\mathrm{CO}]^{+}$, the fragment ions arising by $\mathrm{CO}$ loss from metastable [XxxYyy + $\mathrm{H}]^{+}$formed via FAB ionization in the sector mass spectrometer ${ }^{\mathrm{a}}$

\begin{tabular}{|c|c|c|c|c|c|c|}
\hline \multirow{2}{*}{ 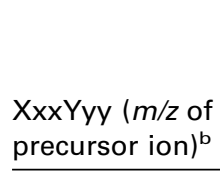 } & \multicolumn{2}{|c|}{$\begin{array}{c}\mathrm{y}_{1} \\
{[\mathrm{Yyy}+\mathrm{H}]^{+}}\end{array}$} & \multicolumn{2}{|c|}{$\begin{array}{l}\mathrm{a}_{1} \text { Immonium } \\
\text { ion from } \\
\text { Xxx residue }\end{array}$} & \multicolumn{2}{|c|}{$\begin{array}{c}\text { Other } \\
\text { fragments }\end{array}$} \\
\hline & $m / z$ & $\%$ & $m / z$ & $\%$ & $m / z$ & $\%$ \\
\hline GlyGly (105) & 76 & 100 & 30 & 16 & $88^{c}$ & 14 \\
\hline GlyAla (119) & 90 & 100 & 30 & 6 & $\begin{array}{r}102^{\mathrm{c}} \\
44^{\mathrm{d}}\end{array}$ & $\begin{array}{r}2 \\
16\end{array}$ \\
\hline AlaGly (119) & 76 & 9 & 44 & 100 & $30^{d}$ & 7 \\
\hline AlaAla (133) & 90 & 30 & 44 & 100 & & \\
\hline Alalle (175) & 132 & 100 & 44 & 9 & & \\
\hline IleAla (175) & 90 & 20 & 86 & 100 & $44^{d}$ & 5 \\
\hline
\end{tabular}

a Relative abundances in \% of base peak intensity, using peak areas. bMass-to-charge ratio of [XxxYyy $+\mathrm{H}-\mathrm{CO}^{+}$.

${ }^{\mathrm{C}} \mathrm{NH}_{3}$ loss.

Immonium ion from Yyy residue. This fragment overlaps with $a_{1}$ for GlyGly and AlaAla.

either absent or minor from the other protonated dipeptides studied.

Selected peptide ions were also formed by ESI and investigated by ion trap mass spectrometry. Under the activation conditions used (vide supra), the CAD spectra of ESI-generated $[\mathrm{M}+\mathrm{H}]^{+}$in the trap are similar with those obtained from FAB-generated ions in the hybrid instrument at low collision energy. With all [M $+\mathrm{H}]^{+}$ions studied, the eliminations of small neutrals $\left(\mathrm{H}_{2} \mathrm{O}, \mathrm{CO}, \mathrm{H}_{2} \mathrm{O}+\mathrm{CO}\right)$ proceed with favorable yields at low collision energy or upon CAD in the ion trap, while backbone cleavages (to $\mathrm{a}_{1}$ and $\mathrm{y}_{1}$ ) become more competitive at high collision energies [22].

The CAD behavior of the $[\mathrm{XxxYyy}+\mathrm{H}]^{+}$ions as a function of collision energy reveals that the losses of small neutrals must be associated with low critical energies, since these reactions are favored when the internal energy of the decomposing ions is low. Increasing the energy available for dissociation promotes backbone fragmentation to $\mathrm{y}_{1}$ and $\mathrm{a}_{1}$ at the expense of small neutral losses. This observation suggests that backbone cleavages require higher critical energies but have more favorable activation entropies (looser transition states) than the eliminations of small neutrals. Evidence for this general expectation was provided in a study of Laskin et al. [22] who analyzed the CAD and SID (surface-induced dissociation) breakdown graphs of $[\text { AlaAla }+\mathrm{H}]^{+}$by RRKM calculations; the resulting dissociation energies and transition state entropies were $1.94 \mathrm{eV}$ and $-1.8 \mathrm{eu}$ for $\mathrm{H}_{2} \mathrm{O}$ loss, $1.92 \mathrm{eV}$ and $1.0 \mathrm{eu}$ for $\mathrm{CO}$ loss, $2.06 \mathrm{eV}$ and $4.3 \mathrm{eu} \mathrm{y}_{1}$ formation, and $2.11 \mathrm{eV}$ and $9.9 \mathrm{eu}$ for $\mathrm{a}_{1}$ formation. Additional relevant data are given in the computational section of our study (vide infra).

\section{Loss of $\mathrm{CO}$ on the $a_{1}-y_{1}$ Pathway}

$[\mathrm{XxxYyy}+\mathrm{H}]^{+}$from the aliphatic dipeptides undergo $\mathrm{CO}$ loss in the metastable time window (Table 1). The
Table 4. $\mathrm{CAD}\left(\mathrm{MS}^{3}\right)$ spectra of $[\mathrm{XxxYyy}+\mathrm{H}-\mathrm{CO}]^{+}$, the fragment ions arising by $\mathrm{CO}$ loss from collisionally activated $[\mathrm{XxxYyy}+\mathrm{H}]^{+}$formed via ESI in the ion trap ${ }^{a}$

\begin{tabular}{|c|c|c|c|c|c|c|}
\hline \multirow{2}{*}{$\begin{array}{l}\text { XxxYyy }(\mathrm{m} / \mathrm{z} \\
\text { of } \\
\text { precursor } \\
\text { ion })^{b}\end{array}$} & \multicolumn{2}{|c|}{$\begin{array}{c}\mathrm{y}_{1} \\
{[\mathrm{Yyy}+\mathrm{H}]^{+}}\end{array}$} & \multicolumn{2}{|c|}{$\begin{array}{c}\mathrm{a}_{1} \\
\text { Immonium } \\
\text { ion from } \\
\mathrm{Xxx} \\
\text { residue }\end{array}$} & \multicolumn{2}{|c|}{$\begin{array}{c}\text { Other } \\
\text { fragments }\end{array}$} \\
\hline & $m / z$ & $\%$ & $m / z$ & $\%$ & $m / z$ & $\%$ \\
\hline GlyGly (105) & 76 & 63 & 30 & - & $88^{c}$ & 100 \\
\hline GlyAla (119) & 90 & 100 & 30 & - & $\begin{array}{r}102^{c} \\
44^{d}\end{array}$ & $\begin{array}{l}21 \\
20\end{array}$ \\
\hline AlaGly (119) & 76 & - & 44 & 100 & & \\
\hline AlaAla (133) & 90 & 16 & 44 & 100 & & \\
\hline Alalle (175) & 132 & 100 & 44 & - & $86^{d}$ & 3 \\
\hline IleAla (175) & 90 & - & 86 & 100 & & \\
\hline
\end{tabular}

a Relative abundances in \% of base peak intensity, using peak heights. ${ }^{b}$ Mass-to-charge ratio of [XxxYyy $+\mathrm{H}-\mathrm{CO}^{+}$.

${ }^{\mathrm{c}} \mathrm{NH}_{3}$ loss.

dImmonium ion from Yyy residue.

high-energy $\mathrm{CAD}\left(\mathrm{MS}^{3}\right)$ spectra of the resulting $[\mathrm{Xxx} Y \mathrm{yy}+\mathrm{H}-\mathrm{CO}]^{+}$products are simple, displaying 2-4 fragment ions (Table 3). All $\mathrm{MS}^{3}$ spectra contain fragments at the $m / z$ values of the $\mathrm{y}_{1}$ and $\mathrm{a}_{1}$ ions of the original dipeptide; $\mathrm{y}_{1}$ and $\mathrm{a}_{1}$ represent the protonated C-terminal amino acid, $[\mathrm{Yyy}+\mathrm{H}]^{+}$, and the immonium cation from the $\mathrm{N}$-terminal residue $(\mathrm{Xxx})$, respectively. One of the latter two fragments is always base peak (Table 3). The immonium ion from the C-terminal residue (Yyy) is also formed from most [XxxYyy $+\mathrm{H}-$ $\mathrm{CO}^{+}$ions; this ion is indistinguishable from $\mathrm{a}_{1}$ if the original dipeptide carries identical residues (GlyGly and AlaAla). A further fragmentation channel, observed only when Gly resides at the N-terminal position, is $\mathrm{NH}_{3}$ loss (Table 3).

Analogous types of fragment ions are observed in low-energy $\mathrm{MS}^{3}$ spectra obtained from ESI-generated ions using the ion trap (Table 4). There is, however, one important difference; now, either $\mathrm{y}_{1}$ or $\mathrm{a}_{1}$ is formed but not both, except with AlaAla (cf. Tables 3 and 4). Persistently, the $\mathrm{y}_{1}$ or $\mathrm{a}_{1}$ fragment dominating the high-energy $\mathrm{MS}^{3}$ spectrum of a $\left[\mathrm{XxxYyy}+\mathrm{H}-\mathrm{CO}^{+}\right.$ ion also appears abundantly in the corresponding lowenergy CAD spectrum. The differences between the data of Tables 3 and 4 reflect the shorter lifetimes of ions dissociating in sector versus ion trap mass spectrometers and the different dynamics of collisional activation in these instruments (vide infra).

Overall, the CAD $\left(\mathrm{MS}^{3}\right)$ characteristics of [XxxYyy + $\mathrm{H}-\mathrm{CO}^{+}$are consistent with proton-bound dimer structures for the fragment ions emerging by $\mathrm{CO}$ loss from the protonated dipeptides. A mechanism leading to such structures, termed the $a_{1}-y_{1}$ pathway, was recently proposed in a theoretical study of the main fragmentation pathways of GlyGly by Paizs and Suhai [23]. Scheme 1 generalizes this mechanism for an aliphatic dipeptide $X x x Y y y$, carrying side chains $R_{1}$ and $R_{2}$ at the $X x x$ and Yyy residues, respectively. 

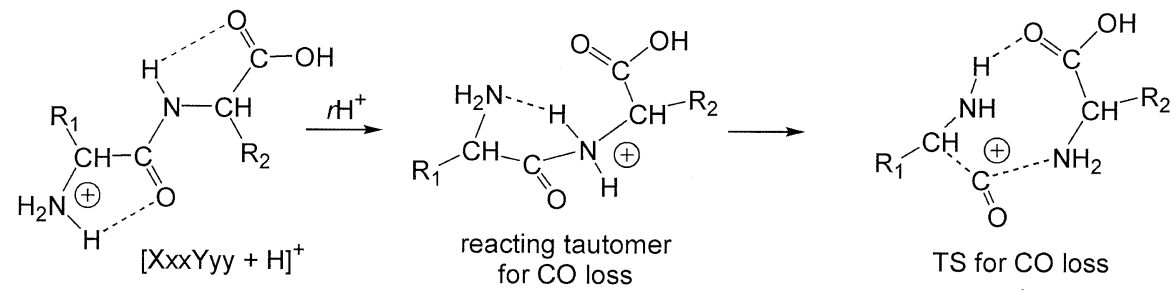

$$
\text { for CO loss }
$$
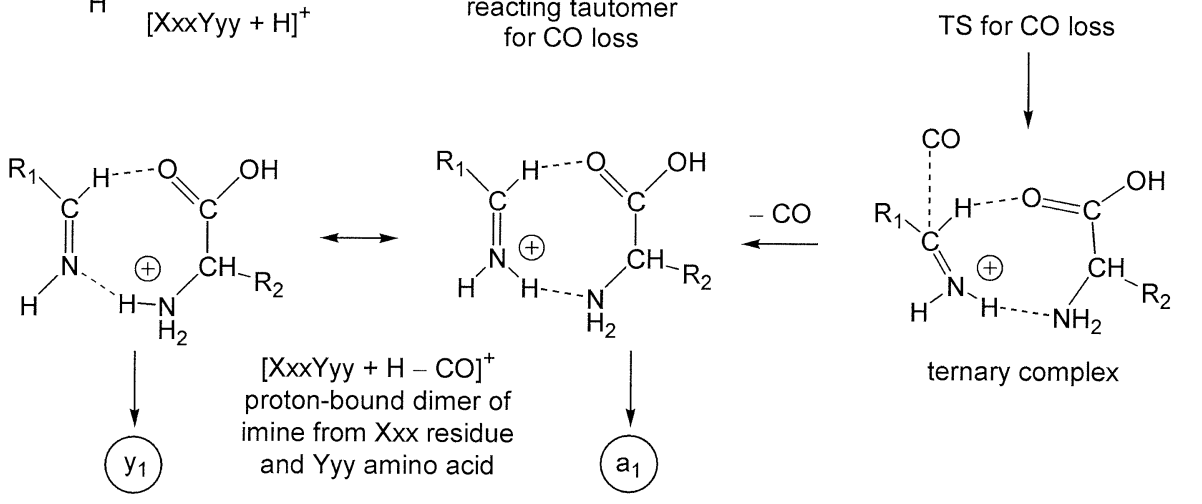

ternary complex

Scheme 1. The $\mathrm{a}_{1}-\mathrm{y}_{1}$ pathway for CO loss from protonated aliphatic dipeptides.

The most basic site of aliphatic dipeptides is the $\mathrm{N}$-terminal amine group (Scheme 1) [39, 40]. When sufficient internal energy is available (in metastable ions or upon $\mathrm{CAD}$ ), the added proton becomes mobile [21] and can be transferred to other, less basic positions. According to the calculations of Paizs and Suhai [23], $\mathrm{CO}$ loss is initiated on the $\mathrm{a}_{1}-\mathrm{y}_{1}$ pathway from a tautomer in which the mobile proton has migrated to the $\mathrm{N}$-atom of the amide bond, thereby weakening the $\mathrm{CO}-\mathrm{NH}$ and $\left(\mathrm{R}_{1}\right) \mathrm{CH}-\mathrm{CO}$ bonds and facilitating the expulsion of $\mathrm{CO}$ to form a ternary complex between the imine of the $\mathrm{Xxx}$ residue, the amino acid Yyy, and the detaching $\mathrm{CO}$ molecule (Scheme 1). CO is easily released from this assembly to produce the proton-bound complex observed experimentally. Consecutive dissociation of the latter complex with retention of the proton by the imine (from $\mathrm{Xxx}$ residue) leads to the $\mathrm{N}$-terminal immonium ion $\mathrm{a}_{1}$, while $\mathrm{H}^{+}$retention by Yyy leads to $\mathrm{y}_{1}$. The latter ion, $\left[\mathrm{Yyy}+\mathrm{H}^{+}\right.$, may dissociate further to yield the immonium ion of the Yyy residue, as a major unimolecular reaction of protonated amino acids is decomposition to the corresponding immonium cations $[9$, 41]. Finally, the loss of ammonia from [GlyGly $+\mathrm{H}$ $-\mathrm{CO}]^{+}$and [GlyAla $\left.+\mathrm{H}-\mathrm{CO}\right]^{+}$(Tables 3 and 4), can be rationalized as a nucleophilic displacement $\left(\mathrm{S}_{\mathrm{N}} 2\right)$ of $\mathrm{NH}_{3}$ by $\mathrm{CH}_{2}=\mathrm{NH}$ in the complex $\mathrm{CH}_{2}=\mathrm{NH} \cdots{ }^{+} \mathrm{H}_{3} \mathrm{NCH}\left(\mathrm{R}_{2}\right) \mathrm{COOH}\left(\mathrm{R}_{2}=\mathrm{H}\right.$ or $\left.\mathrm{CH}_{3}\right) . \mathrm{S}_{\mathrm{N}} 2$ reactions are particularly sensitive to steric hindrance, which could explain why this process occurs only with the least substituted nucleophile $\mathrm{CH}_{2}=\mathrm{NH}$.

The alternative, $\sigma$-bonded structures ${ }^{+} \mathrm{H}_{3} \mathrm{NCH}\left(\mathrm{R}_{1}\right)$ $\mathrm{NHCH}\left(\mathrm{R}_{2}\right) \mathrm{COOH}(\mathbf{I})$ and ${ }^{+} \mathrm{H}_{3} \mathrm{NCH}\left(\mathrm{R}_{1}\right) \mathrm{CONHCH}\left(\mathrm{R}_{2}\right)$ $\mathrm{OH}(\mathrm{II})$, arising by removal of the $\mathrm{N}$ - or C-terminal $\mathrm{CO}$ unit of protonated $\mathrm{Xxx} Y \mathrm{yy}$, respectively, were also considered for $[\mathrm{XxxYyy}+\mathrm{H}-\mathrm{CO}]^{+}$, but were ruled out. CAD of I and II would have produced more and/or other fragments as compared to those observed
(Tables 3 and 4). For example, I should abundantly lose ammonia and water with all $\mathrm{Xxx}$ residues and II should readily dissociate to ${ }^{+} \mathrm{H}_{3} \mathrm{NCH}\left(\mathrm{R}_{2}\right) \mathrm{OH}$ (y-type ion), neither of which takes place. In contrast, the noncovalent structure $\mathrm{R}_{1} \mathrm{CH}=\mathrm{NH} \cdots \mathrm{H}^{+} \cdots \mathrm{H}_{2} \mathrm{NCH}\left(\mathrm{R}_{2}\right) \mathrm{COOH}$ fully agrees with the simple fragmentation patterns observed upon CAD of $[\mathrm{Xxx} Y \mathrm{yy}+\mathrm{H}-\mathrm{CO}]^{+}$.

The energy changes predicted by DFT theory for [GlyGly $+\mathrm{H}^{+}\left(\mathrm{R}_{1}=\mathrm{R}_{2}=\mathrm{H}\right)$ during the events of Scheme $\mathbf{1}$ are depicted in Figure 3. CO loss from protonated GlyGly is endothermic by $88 \mathrm{~kJ} / \mathrm{mol}$ and requires overcoming a barrier of $161 \mathrm{~kJ} / \mathrm{mol}$. The substantial reverse activation energy of this reaction, 73 $\mathrm{kJ} / \mathrm{mol}$, justifies the large kinetic energy release observed in the MI spectra (Table 1). Based on the $\mathrm{T}_{0.5}$ value for $\mathrm{CO}$ loss from [GlyGly $+\mathrm{H}]^{+}(0.33 \mathrm{eV}=32$

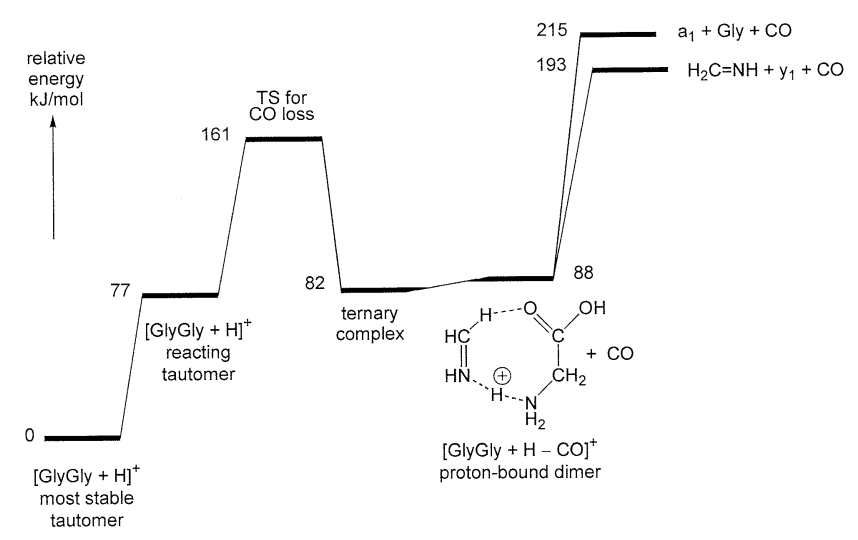

Figure 3. Lowest-energy pathway for loss of $\mathrm{CO}$ and formation of $\mathrm{y}_{1}$ and $\mathrm{a}_{1}$ from protonated GlyGly, calculated at the B3LYP / 6-31 $+\mathrm{G}(\mathrm{d}, \mathrm{p})$ level of theory (see Scheme 1 for structures). The numbers give relative energies versus the lowest-energy geometry of protonated GlyGly and include zero point energy corrections [23]. 
$\mathrm{kJ} / \mathrm{mol}$ ), $\sim 44 \%$ of the reverse activation energy is dissipated into translational energy of the products (proton-bound complex plus CO), the rest being distributed into rovibrational modes (i.e., internal energy) of the products.

In the consecutive dissociation of the proton-bound dimers $[\mathrm{XxxYyy}+\mathrm{H}-\mathrm{CO}]^{+}$to $\mathrm{y}_{1}$ and $\mathrm{a}_{1}$ (Scheme $\mathbf{1}$, Tables 3 and 4), the imine from the $\mathrm{Xxx}$ residue $\left(\mathrm{R}_{1} \mathrm{CH}=\mathrm{NH}\right)$ and the amino acid Yyy $\left(\mathrm{H}_{2} \mathrm{NCH}\left(\mathrm{R}_{2}\right) \mathrm{COOH}\right)$ compete for the proton, and the species of higher proton affinity (PA) should lead to the more abundant fragment ion; this step is thus closely related to a kinetic method experiment [42], as discussed in detail in a recent study of Paizs et al. [38]. All proton-bound dimers [XxxYyy $+\mathrm{H}-\mathrm{CO}]^{+}$(structures $\left.\mathrm{R}_{1} \mathrm{CH}=\mathrm{NH} \cdots \mathrm{H}^{+} \cdots \mathrm{H}_{2} \mathrm{NCH}\left(\mathrm{R}_{2}\right) \mathrm{COOH}\right)$ show the expected $\mathrm{y}_{1} / \mathrm{a}_{1}$ abundance ratio (Tables 3 and 4 ), provided the proton affinities of the imines involved are correctly represented by recently published G2-ab initio or density functional theory values (Table 2) [37, 38]. The PA(imine) values from the NIST database [36] appear to be underestimated and cannot reconcile the $\mathrm{y}_{1} / \mathrm{a}_{1}$ ratios observed from [AlaGly $+\mathrm{H}-\mathrm{CO}]^{+}$and [AlaAla $+\mathrm{H}$ $-\mathrm{CO}^{+}$.

Upon CAD $\left(\mathrm{MS}^{3}\right)$ of $\mathrm{R}_{1} \mathrm{CH}=\mathrm{NH} \cdots \mathrm{H}^{+} \cdots \mathrm{NH}_{2} \mathrm{CH}$ $\left(\mathrm{R}_{2}\right) \mathrm{COOH}$ at high collision energy in the sector instrument, both constituents of the proton-bound dimer compete effectively for the proton, resulting in the observation of $y_{1}$ as well as $a_{1}$ fragments (Table 3). In contrast, $\mathrm{CAD}\left(\mathrm{MS}^{3}\right)$ at low collision energy in the ion trap generally produces only one of these fragments, viz. that arising by proton attachment to the more basic complex constituent, the only exception being the proton-bound dimer from AlaAla, i.e., $\mathrm{CH}_{3} \mathrm{CH}=\mathrm{NH} \cdots \mathrm{H}^{+} \cdots$ Ala (Table 4$)$. In our high-energy CAD experiments ( $\mathrm{keV}$ range), a broad range of internal energies is deposited by a single collision onto the precursor ion which subsequently dissociates in less than a few microseconds; under these conditions, several competitive dissociations can take place simultaneously, depending on the amount of energy gained by a particular precursor ion and the dissociation kinetics [43]. Conversely, low-energy CAD in the trap activates by multiple collisions, each depositing a small amount of internal energy, while millisecond time windows are available for dissociation between collisions [29, 30, 34]. Once the threshold for a fast reaction is reached, the precursor ion reacts by this channel accumulating the corresponding fragment ion. A competitive fast reaction is obstructed unless its critical energy is very similar; the only $[\mathrm{Xxx} Y \mathrm{yy}+\mathrm{H}-\mathrm{CO}]^{+}$dimer yielding both $\mathrm{y}_{1}$ and $\mathrm{a}_{1}$ upon low-energy $\mathrm{CAD}$ is $\mathrm{CH}_{3} \mathrm{CH}=\mathrm{NH} \cdots \mathrm{H}^{+} \cdots$ Ala (Table 4 ), for which the energies needed to form $\mathrm{a}_{1}+$ Ala versus $\mathrm{CH}_{3} \mathrm{CH}=\mathrm{NH}+\mathrm{y}_{1}$ differ by only $6 \mathrm{~kJ} / \mathrm{mol}$ (this is the difference in PA between $\mathrm{CH}_{3} \mathrm{CH}=\mathrm{NH}$ and Ala, cf. Table 2). Multiple collision conditions at low collision energy may, on the other hand, promote consecutive fragmentations if the corresponding energetics are favorable [22]; this is true

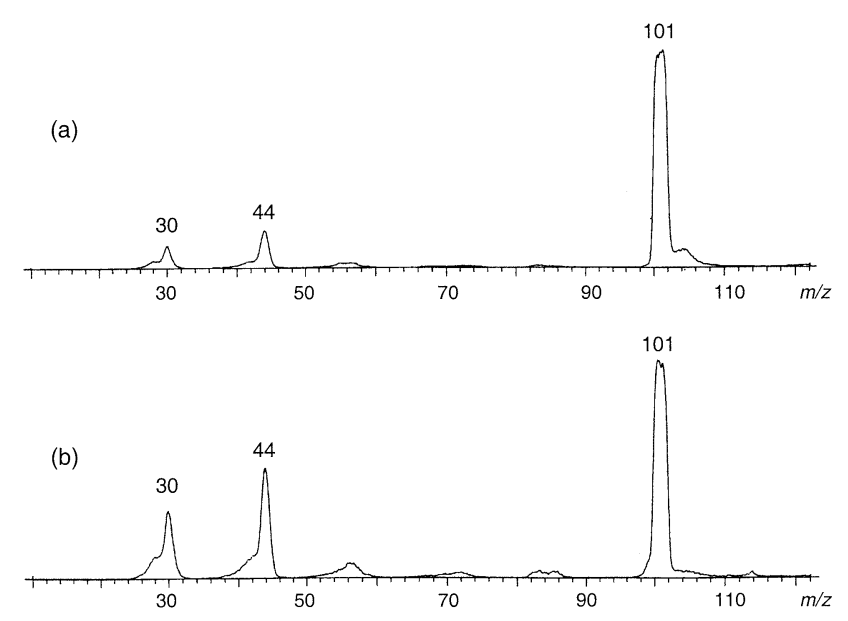

Figure 4. High-energy CAD $\left(\mathrm{MS}^{3}\right)$ spectra of FAB-generated (a) [GlyAla $\left.+\mathrm{H}-\mathrm{H}_{2} \mathrm{O}\right]^{+}(\mathrm{m} / \mathrm{z} 129)$ and (b) [GlyAlaGly $\left.+\mathrm{H}-\mathrm{Gly}\right]^{+}$ $(m / z 129)$ ions. The kinetic energies of the [GlyAla $+\mathrm{H}]^{+}$and [GlyAlaGly $+\mathrm{H}]^{+}$precursor ions were adjusted at 5.8 and 8.0 $\mathrm{keV}$, respectively, to yield $\mathrm{m} / \mathrm{z} 129$ fragments of $5.1 \mathrm{keV}$ kinetic energy in both cases.

for the $\mathrm{y}_{1}$ fragments from the proton-bound dimers $\mathrm{CH}_{2}=\mathrm{NH} \cdots \mathrm{H}^{+} \cdots$ Ala (from GlyAla) and $\mathrm{CH}_{3} \mathrm{CH}=\mathrm{NH} \cdots \mathrm{H}^{+} \cdot$ Ile (from AlaIle), which partly decompose further to the immonium ions of Ala $(\mathrm{m} / \mathrm{z} 44)$ and Ile $(m / z 86)$, respectively (Table 4 ).

As the basicities of the imine from the N-terminus $\left(\mathrm{R}_{1} \mathrm{CH}=\mathrm{NH}\right)$ and/or of the C-terminal amino acid (Yyy) increase, the point may be reached at which the energy levels of products $\mathrm{y}_{1}+\mathrm{R}_{1} \mathrm{CH}=\mathrm{NH}+\mathrm{CO}$ and/or of products $\mathrm{a}_{1}+\mathrm{Yyy}+\mathrm{CO}$ drop below the energy level of the rate-determining transition state for $\mathrm{CO}$ loss (cf. Scheme 1 and Figure 3). In such a situation, [XxxYyy + $\mathrm{H}-\mathrm{CO}^{+}$will spontaneously decay further to $\mathrm{y}_{1}$ and/or $\mathrm{a}_{1}$ and the tandem mass spectra of [XxxYyy + $\mathrm{H}]^{+}$should contain no detectable signal for the product of CO loss. It is very likely that this case applies to $\left[\right.$ GlyPhe $+\mathrm{H}^{+}{ }^{+},[\text {AlaTrp }+\mathrm{H}]^{+}$, and $[\operatorname{TrpAla}+\mathrm{H}]^{+}$, which incorporate relatively basic Phe or Trp residues (Table 2) and whose MI spectra (Table 1) contain significant $\mathrm{y}_{1}$ or $\mathrm{a}_{1}$ ions but no detectable fragment for CO loss.

\section{Mechanistic Pathway for the Loss of $\mathrm{H}_{2} \mathrm{O}$}

CAD of the dehydration product of [XxxYyy $+\mathrm{H}]^{+}$ ions from aliphatic dipeptides produces very similar fragmentation patterns as CAD of the $b_{2}$ ions from tripeptides with the same two $\mathrm{N}$-terminal residues. This is illustrated in Figure 4, which compares the highenergy CAD $\left(\mathrm{MS}^{3}\right)$ spectrum of metastably generated [GlyAla $\left.+\mathrm{H}-\mathrm{H}_{2} \mathrm{O}\right]^{+}$to that of metastably generated $\mathrm{b}_{2}$ from [GlyAlaGly $\left.+\mathrm{H}\right]^{+}$. It has been conclusively established that $b_{2}$ sequence ions from protonated tripeptides have the structure of a protonated oxazolone [6, 10, 20]; hence, the $\mathrm{MS}^{3}$ data provide evidence that the dehydration of protonated aliphatic dipeptides also yields $b_{2}$ ions with protonated oxazolone structures. 
Table 5. $\mathrm{CAD}\left(\mathrm{MS}^{3}\right)$ spectra of $\left[\mathrm{Xxx} Y y y+\mathrm{H}-\mathrm{H}_{2} \mathrm{O}\right]^{+}$, the $\mathrm{b}_{2}$ fragment ions arising by water loss from collisionally activated $[\mathrm{XxxYyy}+\mathrm{H}]^{+}$formed via ESI in the trap ${ }^{* a}$

\begin{tabular}{|c|c|c|c|c|c|c|c|c|}
\hline \multirow{2}{*}{$\begin{array}{l}\text { XxxYyyZzz or } \\
\text { XxxYyy }(\mathrm{m} / \mathrm{z})^{\mathrm{b}} \\
\mathrm{b}_{2} \text { ion from }\end{array}$} & \multicolumn{2}{|c|}{ CO loss $\left(a_{2}\right)$} & \multicolumn{2}{|c|}{$\begin{array}{l}\text { Immonium ion from } \\
\mathrm{Xxx} \text { residue }\left(\mathrm{a}_{1}\right)\end{array}$} & \multicolumn{2}{|c|}{$\begin{array}{l}\text { Immonium ion from } \\
\text { Yyy residue }\end{array}$} & \multicolumn{2}{|c|}{ Other fragments } \\
\hline & $m / z$ & $\%$ & $m / z$ & $\%$ & $m / z$ & $\%$ & $m / z$ & $\%$ \\
\hline GlyGlyGly (115) & 87 & 100 & & & & & $59^{c}$ & 1 \\
\hline GlyGly (115) & 87 & 100 & & & & & & \\
\hline GlyAlaGly (129) & 101 & 100 & & & 44 & 1 & & \\
\hline GlyAla (129) & 101 & 100 & & & 44 & 1 & & \\
\hline AlaGlyGly (129) & 101 & 100 & 44 & 25 & & & d & \\
\hline AlaGly (129) & 101 & 100 & 44 & 28 & & & $111^{\mathrm{e}}$ & 18 \\
\hline AlaAlaAla (143) & 115 & 100 & 44 & 4 & & & $87^{c}$ & 1 \\
\hline \multirow[t]{2}{*}{ AlaAla (143) } & 115 & 100 & 44 & 4 & & & $125^{\mathrm{e}}$ & 1 \\
\hline & & & & & & & $87^{c}$ & 1 \\
\hline Alalle (185) & 157 & 100 & & & 86 & 2 & & \\
\hline \multirow[t]{2}{*}{ IleAla (185) } & 157 & 100 & 86 & 26 & & & $167^{\mathrm{e}}$ & 2 \\
\hline & & & & & & & $139^{f}$ & 3 \\
\hline GlyPhe (205) & 177 & 100 & & & 120 & 1 & & \\
\hline
\end{tabular}

* Select reference CAD $\left(\mathrm{MS}^{3}\right)$ spectra of the same $\mathrm{b}_{2}$ ions formed from tripeptides (loss of C-terminal amino acid) are also included.

${ }^{a}$ Relative abundances in \% of base peak intensity, using peak heights.

${ }^{b}$ Mass-to-charge ratio of $\left[\mathrm{XxxYyy}+\mathrm{H}-\mathrm{H}_{2} \mathrm{O}\right]^{+}$or $[\mathrm{XxxYyyZzz}+\mathrm{H}-\mathrm{Zzz}]^{+}$.

'Loss of $\mathrm{CO}+\mathrm{CO}$.

d Trace of $\mathrm{m} / \mathrm{z} 73$ (loss of $\mathrm{CO}+\mathrm{CO}$ ) and 86 (unassigned).

eLoss of $\mathrm{H}_{2} \mathrm{O}$

fLoss of CO $+\mathrm{H}_{2} \mathrm{O}$.

From the numerous fragment ions observed in the high-energy CAD spectra of $\left[\mathrm{Xxx} Y y y+\mathrm{H}-\mathrm{H}_{2} \mathrm{O}\right]^{+}$, three stand out, viz. the loss of $\mathrm{CO}(\mathrm{m} / \mathrm{z} 101$ in Figure 4), the immonium ion from the $X x x$ residue $\left(m / z 30 ; a_{1}\right.$ ion), and the immonium ion from the Yyy residue $(\mathrm{m} / \mathrm{z} 44$; an "internal" immonium ion). The CO loss and one of the immonium ions are present in the low-energy CAD $\left(\mathrm{MS}^{3}\right)$ spectra, too, which are summarized in Table 5.

For some $b_{2}$ ions, there are minor differences between MS $^{3}$ spectra acquired from dipeptide versus tripeptide precursors. These are more easily detected upon low-energy CAD in the ion trap, where fewer fragments are generated. The most pronounced difference is between the $b_{2}$ ions from [AlaGly $+\mathrm{H}^{+}$and [AlaGlyGly $+\mathrm{H}^{+}$, with only the former undergoing detectable water loss (Table 5). The differences primarily involve the elimination of small neutrals $\left(\mathrm{H}_{2} \mathrm{O}\right.$ or $\mathrm{CO}$, see footnotes in Table 5), which are very sensitive to and thus could be caused by internal energy effects [44]. Alternatively, the extra peaks could arise from small amounts of another structure. O'Hair et al showed that many different oxazolone isomers are formed upon the dehydration of protonated oligoglycines, depending on which carbonyl oxygen is eliminated as the water molecule [14]. Based on the relative abundances of the extra peaks observed in the $\mathrm{MS}^{3}$ spectra (Table 5), the degree of any contamination of the $\mathrm{b}_{2}$ oxazolones from [XxxYyy $\left.+\mathrm{H}\right]^{+}$by isomeric structures must be small and, therefore, is not addressed further in this study.

DFT calculations by Paizs et al. [40] and Aviyente and coworkers [26] indicate that water loss from protonated GlyGly proceeds from a tautomer in which the proton has been transferred to the $\mathrm{OH}$ group of the
C-terminus $[26,40]$. The proton can be shuttled to this position from the N-terminus [26] (the most basic site) or from the oxygen [26] or nitrogen atoms [40] of the amide group. The lowest-energy pathway involves $\mathrm{H}^{+}$ transfer from the amide oxygen to $\mathrm{COOH}$, as shown in Scheme 2 for the general dipeptide $\mathrm{XxxYyy}$; the corresponding energetics for protonated GlyGly are given in Figure 5 and agree well with those reported by Aviyente et al. [26]. Since the difference in basicity between the N-terminal amine group and the amide $\mathrm{O}$-atom is small (Figure 5), both these tautomers should be populated during ion formation by FAB or ESI; the most stable conformer of amide-protonated XxxYyy carries a strong hydrogen bond between the protonated site and the $\mathrm{NH}_{2}$ group, which facilitates proton transfer between these two positions (Scheme 2). The reacting geometry for $\mathrm{H}_{2} \mathrm{O}$ loss is reached after rotation of the latter conformer to one with different hydrogen bonding arrangements that enable proton transfer to the C-terminal $\mathrm{OH}$ group. Upon proton transfer to the $\mathrm{OH}$ group, the newly formed $\mathrm{H}_{2} \mathrm{O}$ molecule detaches as an oxazolone ring is formed; this rate-determining step (Figure 5) generates an ion-molecule complex between the emerging protonated oxazolone and the cleaved water molecule (Scheme 2), which ultimately loses the $\mathrm{H}_{2} \mathrm{O}$ unit to produce $a b_{2}$ ion with oxazolone structure. Note that $\mathrm{H}_{2} \mathrm{O}$ loss necessitates proton transfer to the $\mathrm{C}$-terminal residue, in keeping with the higher yield of this reaction from $\mathrm{Xxx} Y y y$ dipeptides carrying the more basic amino acid at the Yyy location (Table 1). In contrast, $\mathrm{CO}$ loss proceeds through a transition state generating an immonium cation at the N-terminal residue (Scheme 1 and Figure 3). The proton affinities of imines parallel those of the respective amino acids 


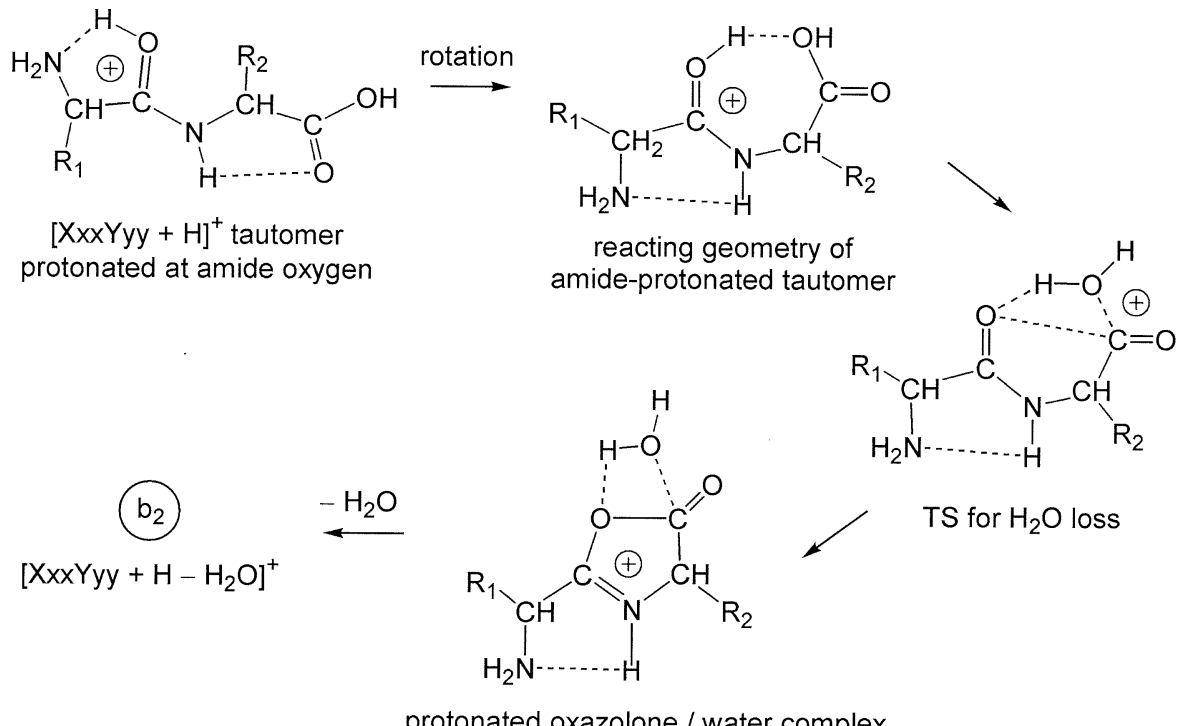

Scheme 2. Pathway for $\mathrm{H}_{2} \mathrm{O}$ loss from protonated aliphatic dipeptides.

(Table 2), explaining why CO loss is favored when the more basic amino acid is incorporated at the $\mathrm{Xxx}$ location (Table 1).

According to the energy diagrams of Figures 3 and 5, the losses of $\mathrm{CO}$ and $\mathrm{H}_{2} \mathrm{O}$ from [GlyGly $\left.+\mathrm{H}\right]^{+}$require very similar critical energies (161 versus $155 \mathrm{~kJ} / \mathrm{mol}$ ) and, thus, should be competitive, as indeed observed; these reactions are important dissociation channels of $[\text { GlyGly }+\mathrm{H}]^{+}$at low internal energies (Figures 1, 2 and Table 1). Both dissociations are associated with considerable reverse activation energies of $73 \mathrm{~kJ} / \mathrm{mol}(\mathrm{CO}$ loss) and $49 \mathrm{~kJ} / \mathrm{mol}\left(\mathrm{H}_{2} \mathrm{O}\right.$ loss). As mentioned above, a significant fraction of this excess energy is released into translational degrees of freedom upon the loss of $\mathrm{CO}$, as attested by the corresponding broad, flat-topped signal in the MI spectrum (Figure 1a) and the large $\mathrm{T}_{0.5}$ value (32 kJ/mol, cf. Table 1). In sharp contrast, $\mathrm{H}_{2} \mathrm{O}$ loss

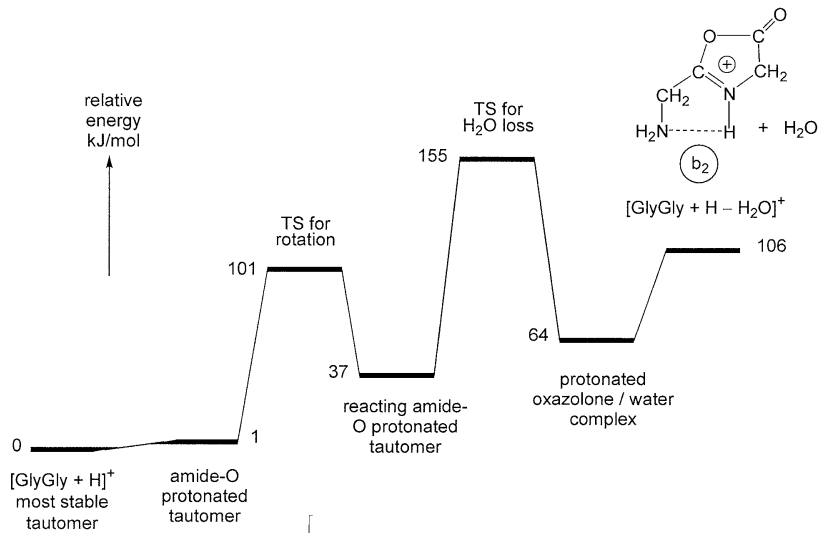

Figure 5. Lowest-energy pathway for the dissociation of protonated GlyGly to $b_{2}+\mathrm{H}_{2} \mathrm{O}$, calculated at the B3LYP/6-31 + G(d,p) level of theory (see Scheme 2 for structures). The numbers give relative energies versus the lowest-energy geometry of protonated GlyGly and include zero point energy corrections. produces a narrower, Gaussian signal in the MI spectrum (Figure 1a), and its kinetic energy release is small $\left(\mathrm{T}_{0.5}<2 \mathrm{~kJ} / \mathrm{mol}\right.$, cf. Table 1$)$; hence, most of the excess energy $(>95 \%$ of $49 \mathrm{~kJ} / \mathrm{mol}$ ) is dissipated as internal energy of the products in this case. The cause of this divergence could be the dramatic difference in stability of the noncovalent complexes arising in the rate-determining steps of $\mathrm{CO}$ versus $\mathrm{H}_{2} \mathrm{O}$ loss; the ternary complex formed upon CO loss is barely bound (Figure 3), while the hydrated oxazolone formed upon $\mathrm{H}_{2} \mathrm{O}$ loss is bound quite strongly (Figure 5). Apparently, the latter complex lives long enough to accommodate the excess energy released during its formation into rovibrational degrees of freedom, as has been proposed by Aviyente et al. [26].

$\mathrm{CAD}$ reveals that the major dissociation channel of the $b_{2}$ ions generated by water loss from [XxxYyy + $\mathrm{H}]^{+}$is $\mathrm{CO}$ expulsion to form the corresponding $\mathrm{a}_{2}$ ions (Figure 4, Table 5). The energetically most favorable mechanism predicted for this reaction by DFT calculations entails the concerted cleavage of two bonds in the oxazolone ring of $b_{2}$ (Scheme 3 ), leading to the release of $\mathrm{CO}$ to form an $\mathrm{a}_{2}$ ion with immonium structure [18]. The other major fragments from $b_{2}$ can be rationalized by consecutive decompositions of $\mathrm{a}_{2}$, as depicted in Scheme 3. In the proposed mechanism, the carbonyl group of $\mathrm{a}_{2}$ is eliminated as a CO molecule to yield [ $\mathrm{a}_{2}$ $-\mathrm{CO}^{+}$, a proton-bound complex of the imines belonging to the $\mathrm{Xxx}$ and Yyy residues [45]. Sequential dissociation of this complex ultimately generates the immonium ions of the $\mathrm{Xxx}$ residue $\left(\mathrm{a}_{1}\right)$ and Yyy residue (an "internal" immonium ion). It has been documented experimentally [6] and computationally [18] that the dissociation $\mathrm{b}_{2} \rightarrow \mathrm{a}_{2}+\mathrm{CO}$ is associated with a considerable reverse barrier that leads to broad, flat- or dish-topped $a_{2}$ peaks in sector instruments (see, for 


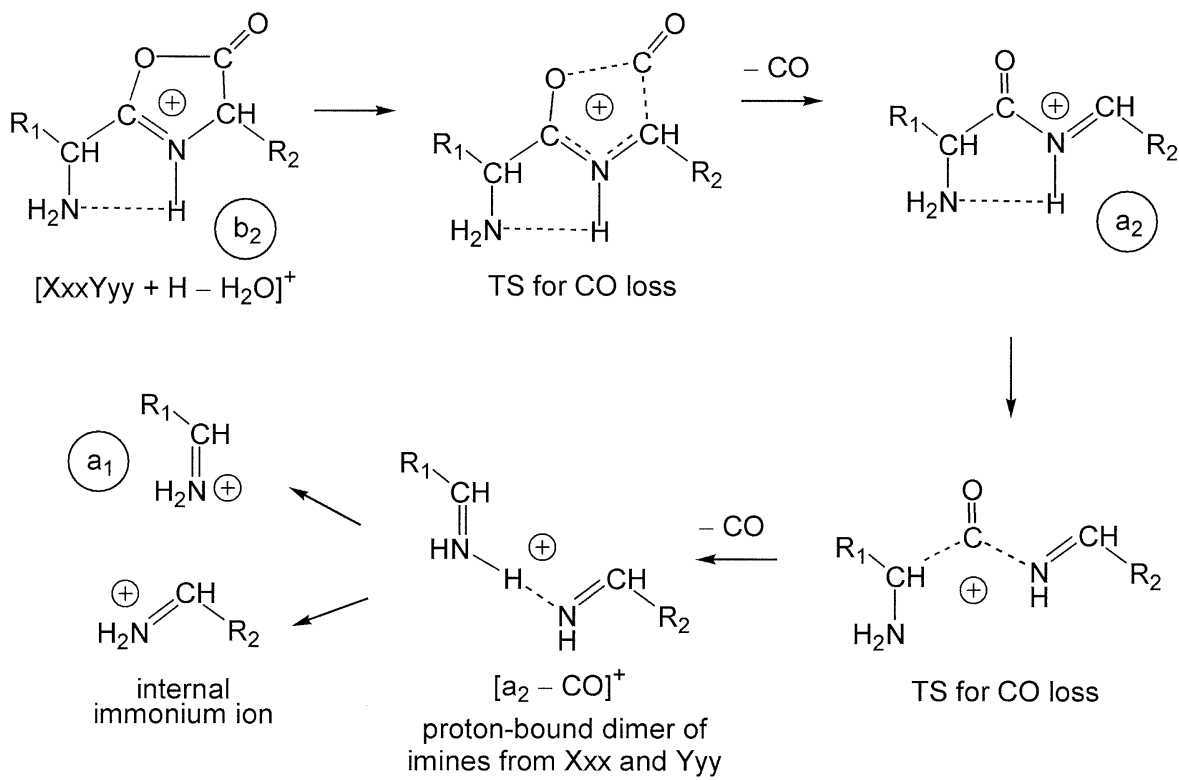

Scheme 3. Fragmentation pathways of $\left[\mathrm{XxxYyy}+\mathrm{H}-\mathrm{H}_{2} \mathrm{O}\right]^{+}\left(\mathrm{b}_{2}\right)$.

example, $m / z 101$ in Figure 4). The successive elimination of a second $\mathrm{CO}$ unit also is accompanied by a reverse barrier. Such energetics is indicated by the MI spectrum of FAB-generated $\mathbf{a}_{2}$ from GlyAla $(m / z$ 101). This spectrum (not shown) contains a broad, flattopped peak at $m / z 73$ originating from CO loss as well as Gaussian signals at $\mathrm{m} / \mathrm{z} 44$ and 30 resulting from the immonium ions of the Ala and Gly residues, respectively; the corresponding relative peak areas (and kinetic energy releases in $\mathrm{eV}$ ) are $46 \%(0.38)$ for $\mathrm{m} / \mathrm{z} 73$, $100 \%(0.05)$ for $\mathrm{m} / \mathrm{z} 44$, and $5 \%(0.08)$ for $\mathrm{m} / \mathrm{z} 30$. The dissociation characteristics of $\mathrm{a}_{2}$ from [GlyAla $+\mathrm{H}^{+}$ both corroborate that $\left[\mathrm{a}_{2}-\mathrm{CO}\right]^{+}$is formed over a transition state that lies higher in energy than the resulting products and also provide supporting evidence for the dissociation sequence proposed in Scheme 3. It is worth noting that this study and previous work $[6,9,41,46]$ have repeatedly shown that the rearrangement elimination of $\mathrm{CO}$ from the backbone of peptide and amino acid ions proceeds with appreciable reverse activation energies.

All processes of Scheme 3 are observed upon highenergy CAD of [XxxYyy $\left.+\mathrm{H}-\mathrm{H}_{2} \mathrm{O}\right]^{+}\left(\mathrm{b}_{2}\right)$ as attested in Figure 4 by the fragmentation pattern of ions with GlyAla sequence; the first CO loss $\left(\mathrm{a}_{2}\right.$ at $\left.m / z 101\right)$ and formation of the Gly and Ala immonium ions $(\mathrm{m} / \mathrm{z} 30$ and 44 , respectively) take place abundantly, as mentioned above, while the loss of two $\mathrm{CO}$ units $\left(\left[\mathrm{a}_{2}-\right.\right.$ $\mathrm{CO}^{+}$at $\mathrm{m} / \mathrm{z}$ 73) only gives a weak signal. The low relative intensity of $\left[\mathrm{a}_{2}-\mathrm{CO}\right]^{+}$is attributed to an efficient further fragmentation of this proton-bound complex (Scheme 3), promoted by the internal energy gained from the reverse barriers of the sequential $\mathrm{CO}$ losses preceding $\left[\mathrm{a}_{2}-\mathrm{CO}\right]^{+}$formation.

Also [XxxYyy $\left.+\mathrm{H}-\mathrm{H}_{2} \mathrm{O}\right]^{+}\left(\mathrm{b}_{2}\right)$ ions formed in the ion trap dissociate to $\mathrm{a}_{2}+\mathrm{CO}$ upon CAD (Table 5). The loss of a second $\mathrm{CO}$ unit to form $\left[\mathrm{a}_{2}-\mathrm{CO}\right]^{+}$is either not observed or gives rise to a signal just above noise level for the reason presented above. From the immonium ions that can be formed by consecutive dissociation of $\left[\mathrm{a}_{2}-\mathrm{CO}\right]^{+}$(Scheme 3), only one is generated during $\mathrm{CAD}$ in the trap, viz. that corresponding to the more basic imine in the $\left[\mathrm{a}_{2}-\mathrm{CO}\right]^{+}$proton-bound dimer (see Scheme 3 and entries for GlyAla versus AlaGly and AlaIle versus IleAla in Table 5). This divergence vis à vis high-energy CAD conditions (Figure 4) is due to the different activation mechanisms and ion lifetimes in beam versus trap instruments, as has been explained in the previous section. It is noticed that the immonium ion observed is more abundant (relative to the $\mathrm{a}_{2}$ base peak), if it originates from the $\mathrm{N}$-terminal $\mathrm{Xxx}$ residue, cf. relative abundances of $m / z 44$ from sequences GlyAla versus AlaGly and of $\mathrm{m} / \mathrm{z} 86$ from sequences AlaIle versus IleAla in Table 5 . The incipient proton-bound complex emerging from the second $\mathrm{CO}$ loss carries the charge at the $\mathrm{N}$-terminal imine (Scheme 3 ). If the more basic amino acid residue also resides at the $\mathrm{N}$-terminus, no proton transfer is needed to create the corresponding $\mathrm{N}$-terminal immonium ion, which improves the kinetics of formation of this immonium ion and, thereby, increases its abundance.

The CAD $\left(\mathrm{MS}^{3}\right)$ characteristics of [PheGly $+\mathrm{H}-$ $\left.\mathrm{H}_{2} \mathrm{O}\right]^{+}$are completely analogous to those of the aliphatic $\left[\mathrm{XxxYyy}+\mathrm{H}-\mathrm{H}_{2} \mathrm{O}\right]^{+}$ions (Table 5), in agreement with a common structure and similar unimolecular reactivities for the respective $b_{2}$ ions. In contrast, the CAD fragmentation patterns of $b_{2}$ from $\left[\text { GlyAsp }+\mathrm{H}^{+} \text {and [AspGly }+\mathrm{H}\right]^{+}$are distinct (cf. Tables 5 and 6); the fragments observed are consistent with oxazolone structures that decompose uniquely because their aspartyl $\left(\mathrm{CH}_{2} \mathrm{COOH}\right)$ substituents open new reaction channels (Schemes 4 and 5 ). The $b_{2}$ ion 
Table 6. $\mathrm{CAD}\left(\mathrm{MS}^{3}\right)$ spectra of the $\mathrm{b}_{2}$ ions arising by water loss from collisionally activated [GlyAsp $+\mathrm{H}]^{+}$and [AspGly + $\mathrm{H}]^{+}$(both at $m / z$ 191) formed via ESI in the ion trap ${ }^{\mathrm{a}}$

\begin{tabular}{rccc}
\hline & & $\begin{array}{c}\text { [GlyAsp }+ \\
\mathrm{H}-\mathrm{H}_{2} \mathrm{O}^{+} \\
\% / z\end{array}$ & $\begin{array}{c}{[\text { AspGly }+} \\
\left.\mathrm{H}-\mathrm{H}_{2}\right]^{+} \\
\%\end{array}$ \\
\hline \hline 156 & Loss of (ion) & 2 & 73 \\
155 & $\mathrm{NH}_{3}$ & & 100 \\
145 & $\mathrm{H}_{2} \mathrm{O}$ & 58 & 18 \\
127 & $\mathrm{CO}\left(\mathrm{a}_{2}\right)$ & $100^{\mathrm{b}}$ & $67^{\mathrm{c}}$ \\
101 & $\mathrm{CO}+\mathrm{H}_{2} \mathrm{O}$ & 11 & \\
99 & $\mathrm{CO}+\mathrm{CO}_{2}$ & & 4 \\
\hline
\end{tabular}

aRelative abundances in \% of base peak intensity, using peak heights. ${ }^{\text {b }} \mathrm{CO}$ loss precedes $\mathrm{H}_{2} \mathrm{O}$ loss (Scheme 4).

${ }^{c} \mathrm{CO}$ loss follows $\mathrm{H}_{2} \mathrm{O}$ loss (Scheme 5).

with GlyAsp sequence undergoes abundantly $\mathrm{CO}$ loss to produce the corresponding $\mathrm{a}_{2}$ ion, in analogy to the aliphatic $b_{2}$ ions discussed above. Consecutive $\mathrm{CO}_{2}$ elimination can, however, take place in this $\mathrm{a}_{2}$ ion to produce a resonance-stabilized $\left[\mathrm{a}_{2}-\mathrm{CO}_{2}\right]^{+}$ fragment, as rationalized in Scheme 4. A competitive reaction, involving transfer of the proton to the hydroxyl group of the aspartyl side chain followed by $\mathrm{H}_{2} \mathrm{O}$ loss and cyclization is also possible (Scheme 4); this reaction is reminiscent of oxazolone ion formation from protonated dipeptides (Scheme 2 ) and leads to the $\left[\mathrm{a}_{2}-\mathrm{H}_{2} \mathrm{O}\right]^{+}$fragment, which is the predominant CAD product in the ion trap (Table 6). Conversely, the $b_{2}$ ion with AspGly sequence contains the $\mathrm{CH}_{2} \mathrm{COOH}$ at a position that enables $\mathrm{NH}_{3}$ and $\mathrm{H}_{2} \mathrm{O}$ losses, as depicted in Scheme 5; the latter fragment, i.e., $\left[b_{2}-\mathrm{H}_{2} \mathrm{O}\right]^{+}$, still contains an oxazolone substructure from which sequential $\mathrm{CO}$ loss can occur (Scheme 5). Previous studies by Harrison and Tu [47] and Wysocki et al. $[48,49]$ showed that the side chain of aspartic acid residues can participate in the backbone fragmentations of protonated peptides. Our results on the Asp-containing $b_{2}$ ions reveal further that Asp side chain involvement also occurs in the consecutive fragmentations of the backbone ions.

\section{Mechanistic Pathway for the Loss of $\mathrm{NH}_{3}$}

Significant signals for ammonia loss are observed only in the tandem mass spectra of [PheGly $+\mathrm{H}^{+}$and $[\operatorname{TrpAla}+\mathrm{H}]^{+}$(Table 1); this reaction proceeds with very low yield $(<1 \%)$ or not at all from the other protonated dipeptides studied. Two common properties of PheGly and TrpAla are the relatively high proton affinity for their N-terminal residue (Table 2) and the presence of methylene hydrogens in $\alpha$-position to an aromatic group ("benzylic" $\mathrm{H}$-atoms) near the $\mathrm{N}$-terminus. The first property increases the population of $\mathrm{N}$-terminally protonated tautomer, from which a $\mathrm{NH}_{3}$ molecule can be cleaved, while the second property provides $\mathrm{H}$-atoms that can easily be transferred to produce a stable $\left[\mathrm{XxxYyy}+\mathrm{H}-\mathrm{NH}_{3}\right]^{+}$fragment. With this insight at hand, the fragments generated upon low-energy $\mathrm{CAD}\left(\mathrm{MS}^{3}\right)$ of $\left[\mathrm{PheGly}+\mathrm{H}-\mathrm{NH}_{3}\right]^{+}$in the ion trap (Figure 6) allow for elucidation of the structure and unimolecular chemistry of this ion (Scheme 6).

Ammonia loss from N-terminally protonated [PheGly $+\mathrm{H}]^{+}$, accompanied by migration of the proton charge to the amide oxygen, gives rise to ion III (Scheme 6), which constitutes a protonated $\mathrm{N}$-acylglycine, analogous to N-benzoylglycine. Such ions resemble protonated dipeptides and, thus can undergo consecutive $\mathrm{H}_{2} \mathrm{O}$ and $\mathrm{CO}$ losses to form $\mathrm{b}$ - and a-type fragments, respectively [6, 10]; from III, these fragments appear at $m / z 188\left(\mathrm{H}_{2} \mathrm{O}\right.$ loss $)$ and $160\left(\mathrm{H}_{2} \mathrm{O}+\mathrm{CO}\right.$ loss $)$, cf. Figure 6 and Scheme 6 . The loss of a second $\mathrm{CO}$ unit,

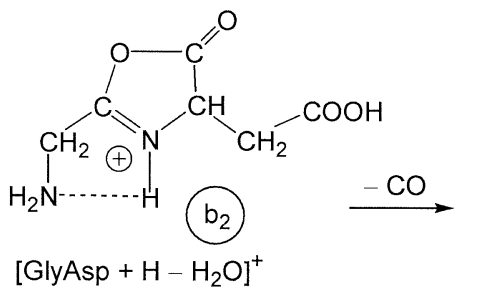

$\left[\text { GlyAsp }+\mathrm{H}-\mathrm{H}_{2} \mathrm{O}\right]^{+}$

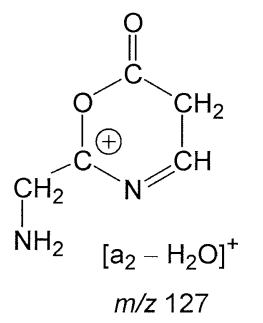

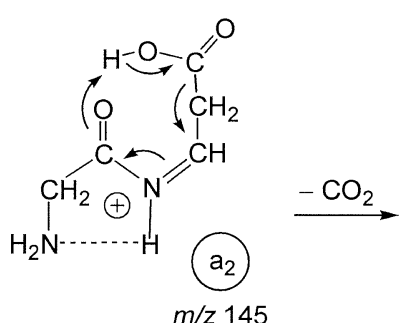
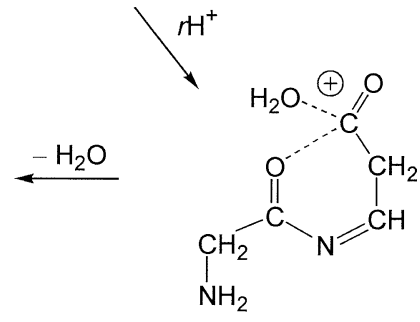

$\mathrm{NH}_{2}$

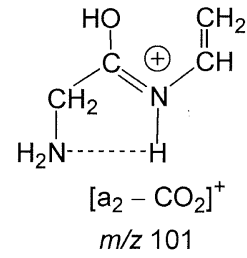

Scheme 4. Major fragmentation pathways of $b_{2}$ ion from protonated GlyAsp. The arrows in $a_{2}$ designate the rearrangement leading to $\mathrm{CO}_{2}$ loss. 


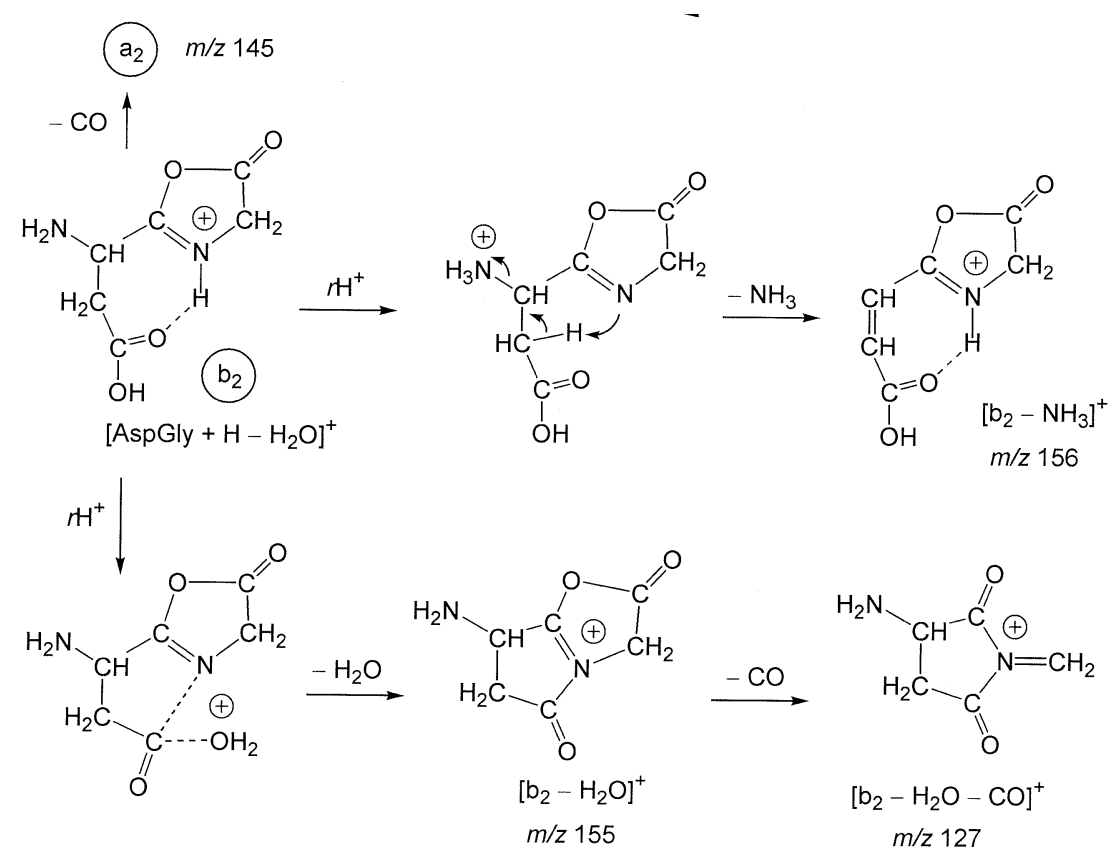

Scheme 5. Major fragmentation pathways of $b_{2}$ ion from protonated AspGly.

a common reaction of a-type ions (vide supra), creates $\mathrm{m} / \mathrm{z}$ 132. If the proton charge migrates to the amide nitrogen during $\mathrm{NH}_{3}$ loss from [PheGly $\left.+\mathrm{H}\right]^{+}$, isomer IV is generated instead (Scheme 6), which can be viewed as a loosely bonded complex between Gly and a resonance-stabilized acylium cation. IV reconciles the fragments arising by scission of Gly $(m / z$ 131), Gly + CO $(m / z 103)$, and CO $(m / z 178)$, cf. Scheme 6 . The loss of $\mathrm{CH}_{2}=\mathrm{C}=\mathrm{O}(\mathrm{m} / \mathrm{z}$ 164; omitted from Scheme 6) can also originate from IV, if Gly attacks at the benzylic C-atom of the acylium cation and the resulting ion, viz. $\mathrm{PhCH}(\mathrm{CH}=\mathrm{C}=\mathrm{O})^{+} \mathrm{H}_{2} \mathrm{NCH}_{2} \mathrm{COOH}$ (isomer $\mathrm{V}$ ), releases ketene to produce $\mathrm{PhCH}={ }^{+} \mathrm{HNCH}_{2} \mathrm{COOH}(\mathrm{m} / z$ 164).

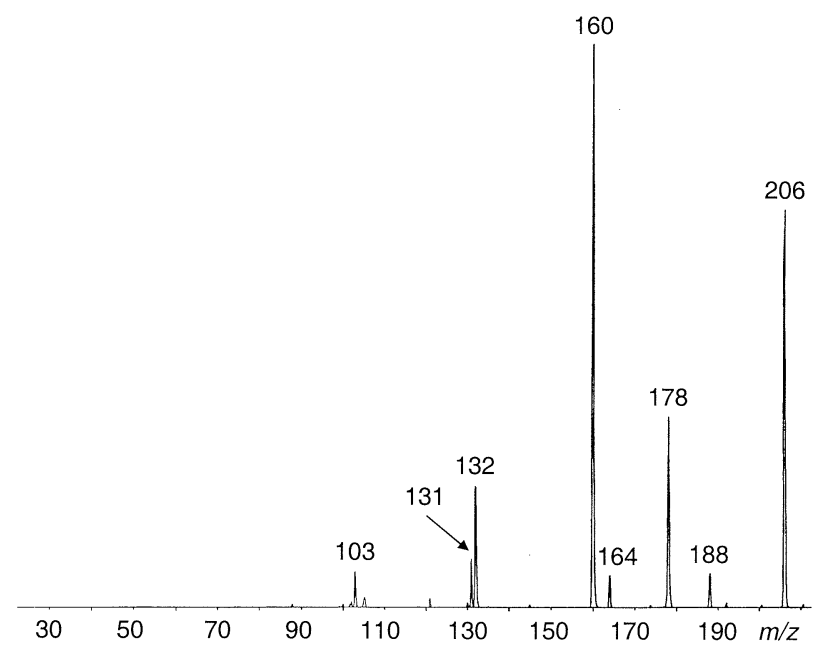

Figure 6. Low-energy CAD $\left(\mathrm{MS}^{3}\right)$ spectrum of ESI-generated $\left[\text { PheGly }+\mathrm{H}-\mathrm{NH}_{3}\right]^{+}$ions $(m / z 206)$ at $\mathrm{V}_{p-p}=0.55 \mathrm{~V}$.

\section{Conclusions}

The lowest-energy fragmentations of protonated dipeptides are intramolecular condensation reactions that release small, stable neutrals, mainly $\mathrm{CO}$ and $\mathrm{H}_{2} \mathrm{O}$. The fragments from these reactions are formed with high yield at threshold energies, but are readily depleted by consecutive decompositions as the internal energy of $[\mathrm{XxxYyy}+\mathrm{H}]^{+}$is increased. The latter reactions are important sources of backbone fragments (sequence ions $a_{2}, a_{1}, y_{1}$ ) and of fragments diagnostic of the individual amino acids present in the dipeptide (amino acid immonium cations).

The fragmentation patterns observed in beam (sector- or quadrupole-based) and trap instruments often differ, reflecting the internal energy distributions deposited in the corresponding collisional activation steps and the time intervals available for subsequent dissociation. Competitive dissociations are best probed by CAD in a beam arrangement, where a broader range of internal energies is deposited and reactions must be completed within microseconds to be observable. The incremental, stepwise activation in the ion trap, coupled with the longer time available for dissociation, promotes sequential fragmentations, with the lowest-energy process dominating in each step, which may not be a sequence-characteristic ion (see discussion of immonium ion generation from $b_{2}$ in the trap). On the other hand, the ion trap easily permits multiple-stage MS/MS experiments to unveil the origin(s) of specific fragments, and combined beam and trap instruments offer a powerful tool for the elucidation of the rather complex gas-phase chemistry of protonated peptides.

Several dissociations of $[\mathrm{XxxYyy}+\mathrm{H}]^{+}$, including 


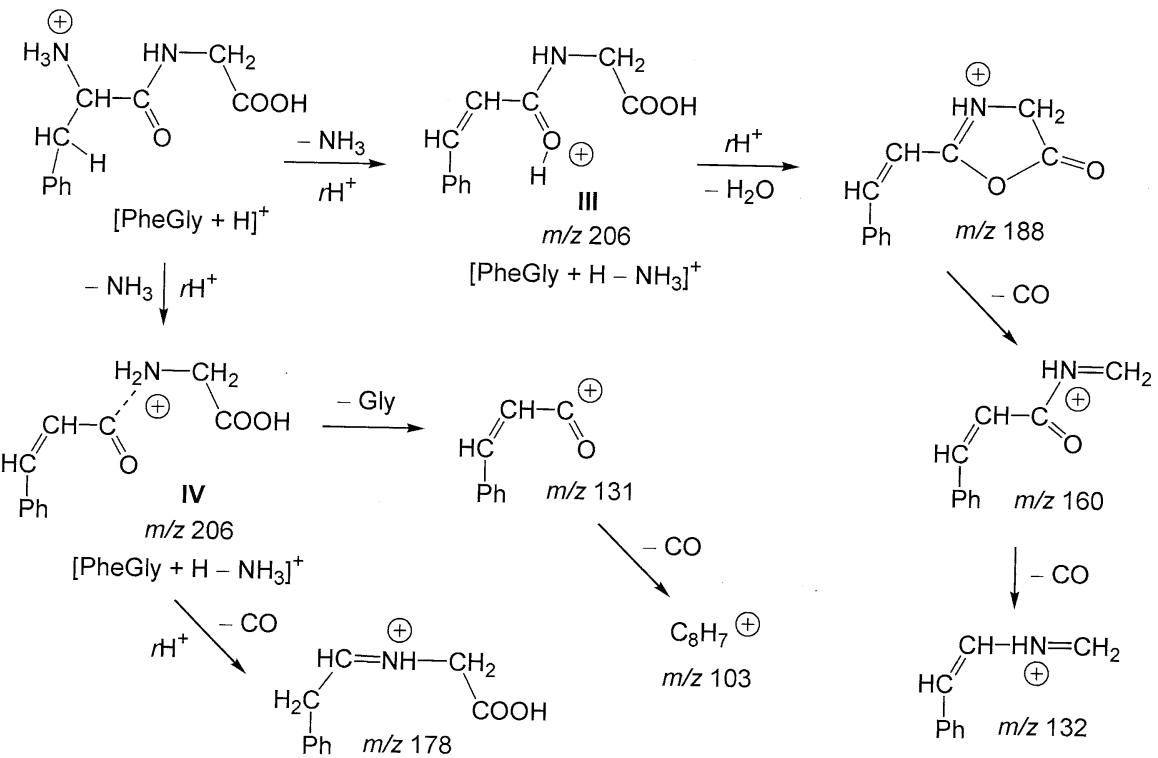

Scheme 6. Formation and dissociations of the ion generated by $\mathrm{NH}_{3}$ loss from protonated PheGly.

the principal condensations via $\mathrm{CO}$ and $\mathrm{H}_{2} \mathrm{O}$ losses, progress through ion-molecule complexes whose constituents compete for the proton charge during the dissociation event. Since these constituents originate from the $\mathrm{Xxx}$ and Yyy residues, the basicities of the latter play an important role in determining which dissociation pathways will predominate from a given dipeptide. It is noteworthy that $\mathrm{CO}$ and $\mathrm{H}_{2} \mathrm{O}$ are eliminated with considerable reverse activation energies, but that kinetic energy release measurements detect only the reverse barrier of the $\mathrm{CO}$ loss and not that of the $\mathrm{H}_{2} \mathrm{O}$ loss. In the latter case, accompanying computational methods are imperative for ascertaining the correct dissociation mechanism; in both cases, theory provides mechanistic details that are not obvious from tandem mass spectra but necessary to understand the observed experimental trends.

\section{Acknowledgments}

The authors thank the National Science Foundation (CHE0111128) for generous support of this project and the Ohio Board of Regents-Hayes Investment Fund Program for funds to acquire mass spectrometers used in this study.

\section{References}

1. Biemann, K. Sequencing of Peptides by Tandem Mass Spectrometry and High-Energy Collision-Induced Dissociation. Methods Enzymol. 1990, 193, 455-479.

2. Papayannopoulos, I. A. The Interpretation of CollisionInduced Dissociation Tandem Mass Spectra of Peptides. Mass Spectrom. Rev. 1995, 14, 49-73.

3. Kinter, M.; Sherman, N. E. Protein Sequencing and Identification Using Tandem Mass Spectrometry; Wiley-Interscience: New York, 2000; pp 64-116.
4. Ballard, K. D.; Gaskell, S. J. Dehydration of Peptide $[\mathrm{M} \mathrm{H}]^{+}$ Ions in the Gas Phase. J. Am. Soc. Mass Spectrom. 1993, 4, $477-481$.

5. Cordero, M. M.; Houser, J. J.; Wesdemiotis, C. The Neutral Products Formed During Backbone Fragmentations of Protonated Peptides in Tandem Mass Spectrometry. Anal. Chem. 1993, 65, 1594-1601.

6. Yalcin, T.; Khouw, C.; Csizmadia, I. G.; Peterson, M. R.; Harrison, A. G. Why are b Ions Stable Species in Peptide Spectra? J. Am. Soc. Mass Spectrom. 1995, 6, 1165-1174.

7. Yalcin, T.; Csizmadia, I. G.; Peterson, M. R.; Harrison, A. G. The Structure and Fragmentation of $\mathrm{b}_{n}(n \geq 3)$ Ions in Peptide Spectra. J. Am. Soc. Mass Spectrom. 1996, 7, 233-242.

8. Dongré, A. R.; Jones, J. L.; Somogyi, Á.; Wysocki, V. H. Influence of Peptide Composition, Gas-Phase Basicity, and Chemical Modification on Fragmentation Efficiency: Evidence for the Mobile Proton Model. J. Am. Chem. Soc. 1996, 119, 8365-8374.

9. Ambihapathy, K.; Yalcin, T.; Leung, H.-W.; Harrison, A. G. Pathways to Immonium Ions in the Fragmentation of Protonated Peptides. J. Mass Spectrom. 1997, 32, 209-215.

10. Nold, M. J.; Wesdemiotis, C.; Yalcin, T.; Harrison, A. G. Amide Bond Dissociation in Protonated Peptides. Structures of the N-terminal Ionic and Neutral Fragments. Int. J. Mass Spectrom. Ion Processes 1997, 164, 137-153.

11. Klassen, J. S.; Kebarle, P. Collision-Induced Dissociation Threshold Energies of Protonated Glycine, Glycinamide, and Some Related Small Peptides and Peptide Amino Acids. J. Am. Chem. Soc. 1997, 119, 6552-6563.

12. Reid, G. E.; Simpson, R. J.; O'Hair, R. A. J. A Mass Spectrometric and ab Initio Study of the Pathways for Dehydration of Simple Glycine and Cysteine-Containing Peptide $[\mathrm{M}+\mathrm{H}]^{+}$ ions. J. Am. Soc. Mass Spectrom. 1998, 9, 945-956.

13. O'Hair, R. A. J.; Styles, M. L.; Reid, G. E. Role of the Sulfhydryl Group on the Gas Phase Fragmentation Reactions of Protonated Cysteine and Cysteine Containing Peptides. J. Am. Soc. Mass Spectrom. 1998, 9, 1275-1284.

14. Reid, G. E.; Simpson, R. J.; O'Hair, R. A. J. Probing the Fragmentation Reactions of Protonated Glycine Oligomers via Multistage Mass Spectrometry and Gas Phase Ion Molecule 
Hydrogen/Deuterium Exchange. Int. J. Mass Spectrom. 1999, 190/191, 209-230.

15. Nold, M. J.; Cerda, B. A.; Wesdemiotis, C. Proton Affinities of the N- and C-Terminal Segments Arising Upon the Dissociation of the Amide Bond in Protonated Peptides. J. Am. Soc. Mass Spectrom. 1999, 10, 1-8.

16. Tsaprailis, G.; Nair, H.; Somogyi, Á.; Wysocki, V. H.; Zhong, W.; Futrell, J. H.; Summerfield, S. G.; Gaskell, S. J. Influence of Secondary Structure on the Fragmentation of Protonated Peptides. J. Am. Chem. Soc. 1999, 121, 5142-5154.

17. Paizs, B.; Lendvay, G.; Vékey, K.; Suhai, S. Formation of $b_{2}^{+}$ Ions from Protonated Peptides: An ab Initio Study. Rapid Commun. Mass Spectrom. 1999, 13, 525-533.

18. Paizs, B.; Szlávik, Z.; Lendvay, G.; Vékey, K.; Suhai, S. Formation of $\mathrm{a}_{2}^{+}$Ions of Protonated Peptides. An ab Initio Study. Rapid Commun. Mass Spectrom. 2000, 14, 746-755.

19. Harrison, A. G.; Csizmadia, I. G.; Tang, T.-H.; Tu, Y.-P. Reaction Competition in the Fragmentation of Protonated Dipeptides. J. Mass Spectrom. 2000, 35, 683-688.

20. Polce, M. J.; Ren, D.; Wesdemiotis, C. Dissociation of the Peptide Bond in Protonated Peptides. J. Mass Spectrom. 2000, 35, 1391-1398.

21. Wysocki, V. H.; Tsaprailis, G.; Smith, L. L.; Breci, L. A. Mobile and Localized Protons: A Framework for Understanding Peptide Dissociation. J. Mass Spectrom. 2000, 35, 1399-1406.

22. Laskin, J.; Denisov, E.; Futrell, J. A Comparative Study of Collision-Induced and Surface-Induced Dissociation. 1. Fragmentation of Protonated Dialanine. J. Am. Chem. Soc. 2000, 122, 9703-9714.

23. Paizs, B.; Suhai, S. Theoretical Study of the Main Fragmentation Pathways for Protonated Glycylglycine. Rapid Commun. Mass Spectrom. 2001, 15, 651-663.

24. Paizs, B.; Suhai, S. Combined Quantum Chemical and RRKM Modeling of the Main Fragmentation Pathways of Protonated GGG. II. Formation of $\mathrm{b}_{2}, \mathrm{y}_{1}$, and $\mathrm{y}_{2}$ Ions. Rapid Commun. Mass Spectrom. 2002, 16, 375-389.

25. Paizs, B.; Suhai, S.; Harrison, A. G. Experimental and Theoretical Investigation of the Main Fragmentation Pathways of Protonated H-Gly-Gly-Sar-OH and H-Gly-Sar-Sar-OH. J. Am. Soc. Mass Spectrom. 2003, 14, 000-000.

26. Balta, B.; Aviyente, V.; Lifshitz, C. Elimination of Water from the Carboxyl Group of GlyGlyH ${ }^{+}$. J. Am. Soc. Mass Spectrom. 2003, 14, 1192-1203.

27. Polce, M. J.; Cordero, M. M.; Wesdemiotis, C.; Bott, P. A. A New Trisector Tandem Mass Spectrometer for NeutralizationReionization Studies. Int. J. Mass Spectrom. Ion Processes 1992, 113, 35-58.

28. Busch, K. L.; Glish, G. L.; McLuckey, S. A. Mass Spectrometry/ Mass Spectrometry. Techniques and Applications of Tandem Mass Spectrometry; VCH Publishers: New York, 1988.

29. March, R. E. An Introduction to Quadrupole Iion Trap Mass Spectrometry. J. Mass Spectrom. 1997, 32, 351-369.

30. March, R. E. Quadrupole Ion Trap Mass Spectrometry: Theory, Simulations, Recent Developments, and Applications. Rapid Commun. Mass Spectrom. 1998, 12, 1543-1554.

31. Cooks, R. G.; Beynon, J. H.; Caprioli, R. M.; Lester, G. R. Metastable Ions; Elsevier: Amsterdam, 1973.

32. Holmes, J. L.; Terlouw, J. K. The Scope of Metastable Peak Observations. Org. Mass Spectrom. 1980, 15, 383-396.

33. Holmes, J. L. Assigning Structures to Ions in the Gas Phase. Org. Mass Spectrom. 1985, 20, 169-183.

34. McLuckey, S. A.; Van Berkel, G. J.; Goeringer, D. E.; Glish, G. L. Ion Trap Mass Spectrometry of Externally Generated Ions. Anal. Chem. 1994, 66, 689A-696A.
35. Frisch, M. J.; Trucks, G. W.; Schlegel, H. B.; Scuseria, G. E.; Robb, M. A.; Cheesemann, J. R.; Zakrzewski, V. G.; Montgomery, J. A., Jr.; Stratmann, R. E.; Burant, J. C.; Dapprich, S.; Millam, J. M.; Daniels, A. D.; Kudin, K. N.; Strain, M. C.; Farkas, O.; Tomasi, J.; Barone, V.; Cossi, M.; Cammi, R.; Mennucci, B.; Pomelli, C.; Adamo, C.; Clifford, S.; Ochterski, J.; Petersson, G. A.; Ayala, P. Y.; Cui, Q.; Morokuma, K.; Malick, D. K.; Rabuck, A. D.; Raghavachari, K.; Foresman, J. B.; Cioslowski, J.; Ortiz, J. V.; Stefanov, B. B.; Liu, G.; Liashenko, A.; Piskorz, P.; Komaromi, I.; Gomperts, R.; Martin, R. L.; Fox, D. J.; Keith, T.; Al-Laham, M. A.; Peng, C. Y.; Nanayakkara, A.; Challocombe, M.; Gill, P. M. W.; Johnson, B. G.; Chen, W.; Wong, M. W.; Andres, J. L.; Gonzalez, C.; Head-Gordon, M.; Replogle, E. S.; Pople, J. A. Gaussian 98, Revision A.5; Gaussian, Inc.: Pittsburgh, PA, 1998.

36. Hunter, E. P. L.; Lias, S. G. Evaluated Gas Phase Basicities and Proton Affinities of Molecules: An UpdateJ. Phys. Chem. Ref. Data 1998, 27, 413-656 (Also, at http://webbook.nist.gov/ chemistry/).

37. Hammerum, S.; Solling, T. I. The Proton Affinities of Imines and the Heats of Formation of Immonium Ions Investigated with Composite ab Initio Methods. J. Am. Chem. Soc. 1999, 121, 6002-6009.

38. Paizs, B., Schoelzner, M., Warnkern, U., Suhai, S., Harrison, A. G. Cleavage of the Amide Bond of Protonated Dipeptides, unpublished

39. Wu, J.; Lebrilla, C. B. Gas-Phase Basicities and Sites of Protonation of Glycine Oligomers $\left(\mathrm{Gly}_{n} ; n=1-5\right)$. J. Am. Chem. Soc. 1993, 115, 3270-3275.

40. Paizs, B.; Csonka, I. P.; Lendvay, G.; Suhai, S. Proton Mobility in Protonated Glycylglycine and N-Formylglycylglycinamide: A Combined Quantum Chemical and RRKM Study. Rapid Commun. Mass Spectrom. 2001, 15, 637-650.

41. Beranová, S.; Cai, J.; Wesdemiotis, C. The Unimolecular Chemistry of Protonated Glycine and Its Neutralized form in the Gas Phase. J. Am. Chem. Soc. 1995, 117, 9492-9501.

42. Cooks, R. G.; Wong, P. S. H. Kinetic Method of Making Thermochemical Determinations: Advances and Applications. Acc. Chem. Res. 1998, 31, 379-386.

43. McLafferty, F. W.; Tureček, F. Interpretation of Mass Spectra, 4th ed. University Science Books: Mill Valley, CA, 1993.

44. Levsen, K. Fundamental Aspects of Organic Mass Spectrometry; Verlag Chemie: Weinheim, 1978.

45. El Aribi, H.; Rodriquez, C. F.; Almeida, D. R. P.; Ling, Y.; Mak, W. W.-N.; Hopkinson, A. C.; Siu, K. W. M. Elucidation of Fragmentation Mechanisms of Protonated Peptide Ions and Their Products: A Case Study on Glycylglycylglycine Using Density Functional Theory and Threshold Collision-Induced Dissociation. J. Am. Chem. Soc. 2003, 125, 9229-9236.

46. Polce, M. J.; Wesdemiotis, C. $\alpha$-Glycyl Cation, Radical, and Anion $\left(\mathrm{H}_{2} \mathrm{NCH}^{+/ \cdot /-} \mathrm{COOH}\right)$ : Generation and Characterization in the Gas Phase. J. Am. Soc. Mass Spectrom. 1999, 10, 1241-1247.

47. Harrison, A. G.; Tu, Y.-P. Ion Chemistry of Protonated Aspartic Acid Derivatives. J. Mass Spectrom. 1998, 33, 532-542.

48. Tsaprailis, G.; Somogyi, A.; Nicolaev, E. N.; Wysocki, V. H. Refining the Model for Selective Cleavage at Acidic Residues in Arginine-Containing Protonated Peptides. Int. J. Mass Spectrom. 2000, 195/196, 467-479.

49. Gu, C.; Tsaprailis, G.; Breci, L.; Wysocki, V. H. Selective Gas-Phase Cleavage at the Peptide Bond C-Terminal to Aspartic Acid in Fixed-Charge Derivatives of Asp-Containing Peptides. Anal. Chem. 2000, 72, 5804-5813. 